\title{
Review
}

\section{Ghrelin, des-acyl ghrelin and obestatin: Three pieces of the same puzzle}

\author{
João-Bruno Soares, Adelino F. Leite-Moreira * \\ Department of Physiology, Faculty of Medicine, University of Porto, 4200-319 Porto, Portugal
}

\section{A R T I C L E I N F O}

\section{Article history:}

Received 21 January 2008

Received in revised form

24 February 2008

Accepted 26 February 2008

Published on line 4 March 2008

Keywords:

Ghrelin

Des-acyl ghrelin

Obestatin

GHS-R1a

Ghrelin gene

\begin{abstract}
A B S T R A C T
The major active product of ghrelin gene is a 28-amino acid peptide acylated at the serine 3 position with an octanoyl group, called simply ghrelin. Ghrelin has a multiplicity of physiological functions, affecting GH release, food intake, energy and glucose homeostasis, gastrointestinal, cardiovascular, pulmonary and immune function, cell proliferation and differentiation and bone physiology. Nevertheless, recent developments have shown that ghrelin gene can generate various bioactive molecules besides ghrelin, mainly des-acyl ghrelin and obestatin, obtained from alternative splicing or from extensive post-translational modification. Although their receptors have not yet been identified, they have already proven to be active, having intriguingly subtle but opposite physiological actions to ghrelin. This suggests the existence of a novel endocrine system with multiple effector elements which not only may have opposite actions but may regulate the action of each other. In this review, we summarize the steps which lead to the production of the different ghrelin gene products and examine the most significant differences between them in terms of structure and actions.
\end{abstract}

(C) 2008 Elsevier Inc. All rights reserved.

\section{Contents}

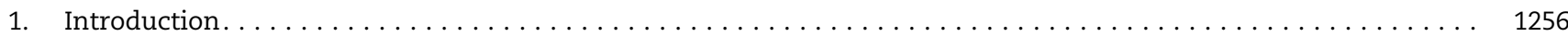

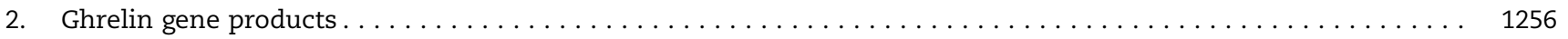

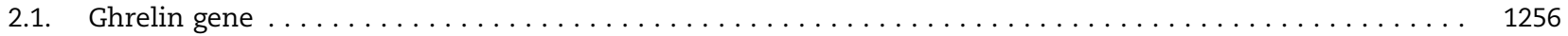

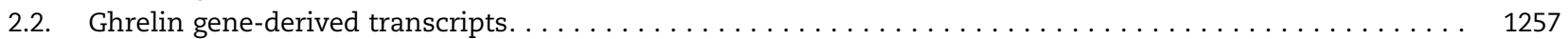

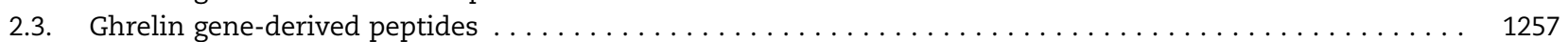

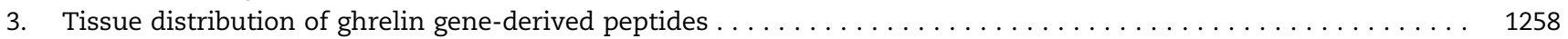

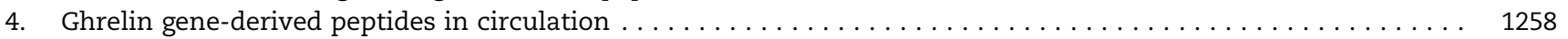

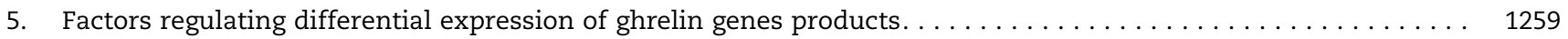

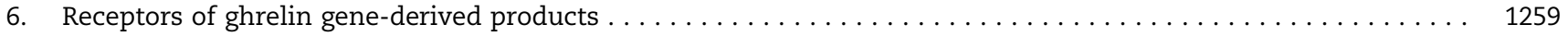

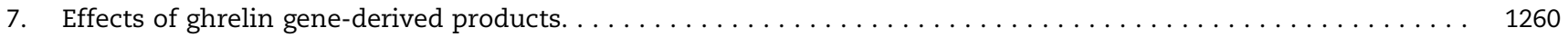

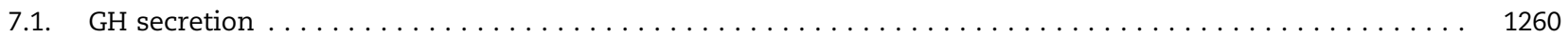

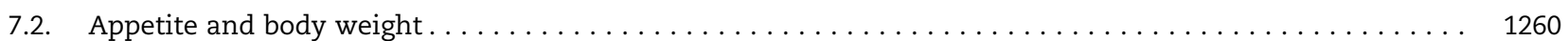

* Corresponding author at: Serviço de Fisiologia da Faculdade de Medicina do Porto, Al. Prof. Hernâni Monteiro, 4200-319 Porto, Portugal. Tel.: +351 225513644; fax: +351 225513646.

E-mail address: amoreira@med.up.pt (A.F. Leite-Moreira). 0196-9781/\$ - see front matter (C) 2008 Elsevier Inc. All rights reserved. doi:10.1016/j.peptides.2008.02.018 


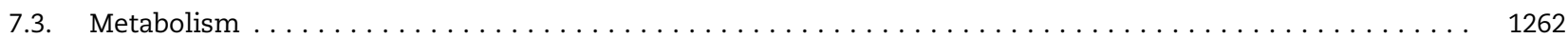

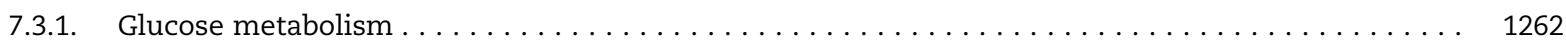

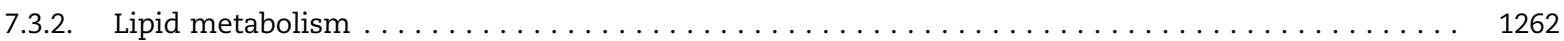

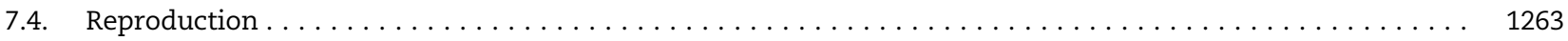

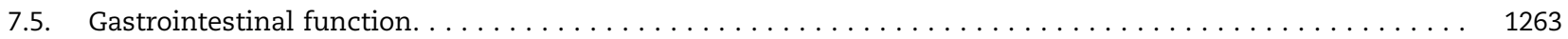

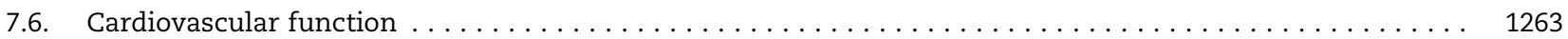

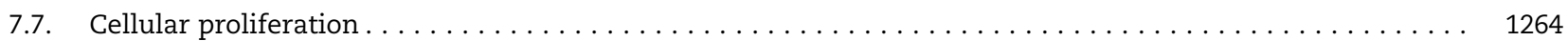

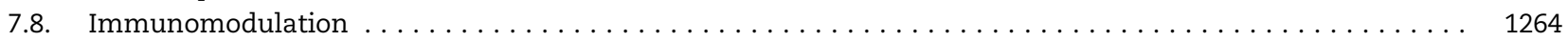

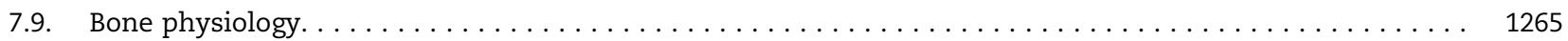

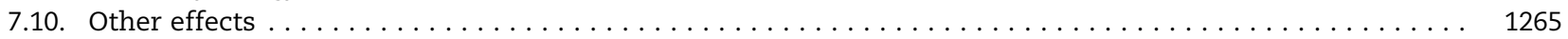

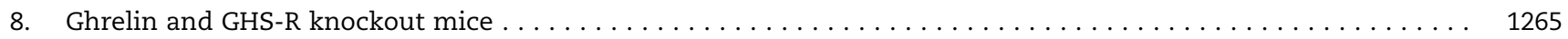

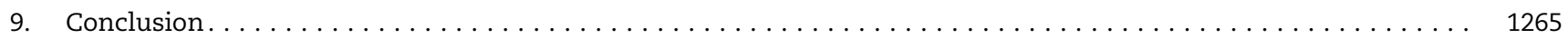

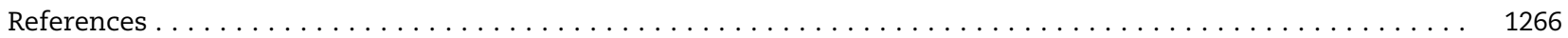

\section{Introduction}

In 1999, ghrelin was discovered in gastric extracts as a natural ligand of the orphan growth hormone secretagogue receptor type 1a (GHS-R1a) [83]. Through this receptor, it acts as a growth hormone releasing peptide and food intake modulator [83]. GHS-R1a is expressed in the hypothalamus and pituitary, which is consistent with the GH-releasing and appetitestimulating effects of ghrelin [72]. However, it has been demonstrated that GHS-R1a is also expressed in other CNS areas and peripheral tissues, where ghrelin is also expressed, suggesting that ghrelin possesses many others effects besides the release of growth hormone (GH) and the stimulation of food intake. In fact, numerous studies have shown that ghrelin also affects energy and glucose homeostasis, gastrointestinal, cardiovascular, pulmonary and immune function, cell proliferation and differentiation and bone physiology [84,91,150].

Although the major active product of ghrelin gene is a 28 amino acid peptide acylated at the serine 3 position with an octanoyl group (C8:0), called simply ghrelin, recent developments have shown that ghrelin gene can generate various bioactive molecules besides ghrelin, mainly des-acyl ghrelin and obestatin, obtained from alternative splicing or from extensive post-translational modifications $[69,70,75,160,162]$. Although their receptors have not yet been identified, they have already proven to be active, having intriguingly subtle but opposite physiological actions to ghrelin $[84,91,150,162]$.
This suggests the existence of a system with multiple effector elements which not only may have opposite actions but may regulate the action of each other. This knowledge may facilitate the study of the physiological, pathological and therapeutic roles of the novel ghrelin system.

In this review, we will summarize the steps which lead to the production of the different ghrelin gene products and will examine the most significant differences between them in terms of structure and actions.

\section{Ghrelin gene products}

\subsection{Ghrelin gene}

Fig. 1 summarizes the steps which lead to the production of the different ghrelin gene products.

The human ghrelin gene is located on chromosome 3p2526. It comprises five exons and three introns, being the short first exon only $20 \mathrm{bp}$ long, which encode part of the $5^{\prime}$ untranslated region [77,81]. Mature ghrelin (i.e., the 28-amino acid GH releasing peptide) is encoded by exons 2 and 3 with the remaining proghrelin peptide sequence contained in exons 4 and 5 [75]. The putative initiation codon ATG is located at nucleotides 34-36, preceded by the consensus initiation sequence, whereas a terminal codon TAG is found 117 codons downstream at position 385-387 [75].

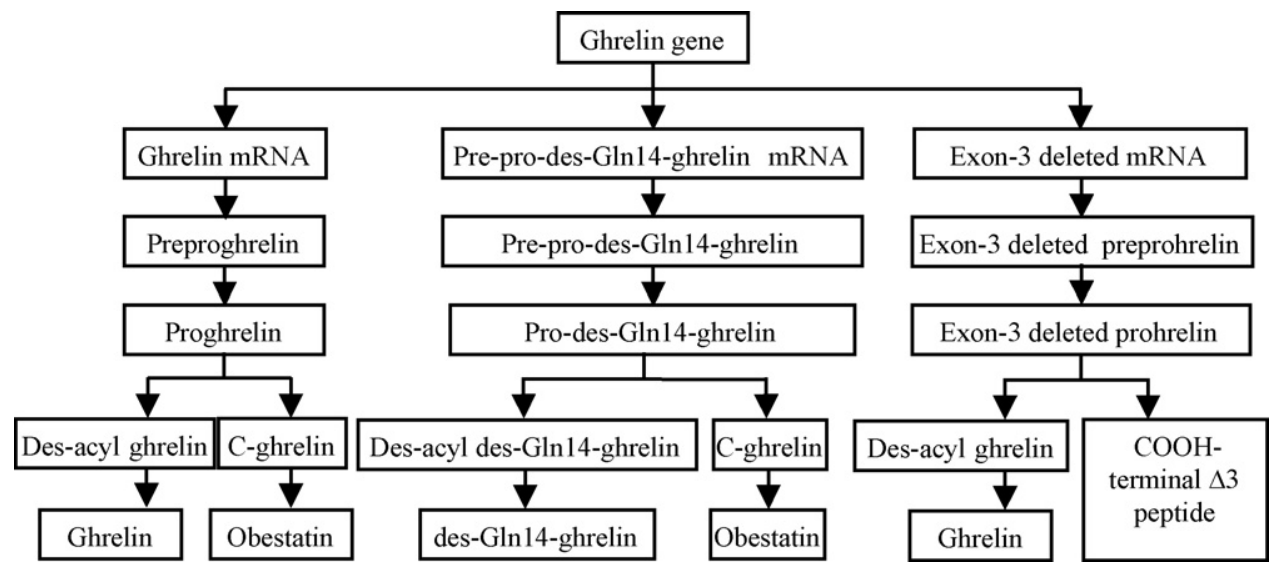

Fig. 1 - Sequential steps of the production of the three major ghrelin gene-derived products. 
Basal transcription activity of the human ghrelin promoter appears to require an essential sequence downstream from the distal initiation site (the noncoding exon 1 region and proximal region of intron 1) [153]. Additionally, multiple putative binding sites for transcription factors have been identified including AP2, basic helix-loop-helix (bHLH), PEA-3, Myb, NF-IL-6, hepatocyte nuclear factor-5, and NF-B, and half-sites for estrogen and glucocorticoid response elements [77,81].

\subsection{Ghrelin gene-derived transcripts}

Two different transcriptional initiation sites have been described in the ghrelin gene: one at -80 and another at -555 relative to the ATG initiation codon, thus originating two distinct mRNA transcripts (forms A and B). Human ghrelin cDNAs studies revealed that mRNA transcript $A$, an alternative splicing product from exon 2 to exon 4 , is the main form of human ghrelin mRNA in vivo [77].

In rat, mouse and pig, a spliced variant without the codon for glutamine in position 14 is produced (pre-pro-des-Gln14ghrelin mRNA) [69]. Although nearly all of the cDNA clones isolated from human stomach encoded the pre-pro-ghrelin mRNA, a few cDNA clones encoded the pre-pro-des-Gln14ghrelin mRNA [70]. However, the amount of des-Gln14-ghrelin from the human stomach and plasma is negligible [70].

As described in detail below, a human exon 3-deleted mRNA transcript has been described in breast and prostate cancer [160]. A murine homologue (exon 4-deleted mRNA transcript) has also been identified in a widely range of murine tissues [75]. It is probable that theses variants, like the pre-prodes-Gln14-ghrelin mRNA, are products of the ghrelin gene produced by alternative splicing mechanisms.

\subsection{Ghrelin gene-derived peptides}

The described wild-type human ghrelin mRNA (transcript A) codes for a 117 amino acid long peptide, preproghrelin. Preproghrelin contains a 23 amino-acid signal peptide and a 94 amino-acid called pro-ghrelin (1-94). This includes the 28 amino acid mature ghrelin (1-28) and a 66 amino acid tail (29-94) $[83,75]$. The enzymes responsible for proteolytic cleavage of preproghrelin to the final products remain largely unknown. However, recent Western blotting and immunocytochemical evidences suggest that proghrelin (1-94) can be cleaved by prohormone convertase 1/3 (PC1/3) in mouse stomach tissue to generate bona fide ghrelin in vivo [163]. The ghrelin sequence starts from Gly1, which directly follows the signal peptide, and the last two residues of ghrelin are Pro27-Arg28, which correspond to a processing signal [83]. Here, the cleavage most frequently occurs following the C-terminal Pro27-Arg28, originating a peptide with 28 amino acids, ghrelin (1-28). Rarely, Arg28 is removed from C-terminus of ghrelin (1-28), most likely by a carboxypeptidase B-like enzyme, originating a peptide with 27 amino acids, ghrelin (1-27), which terminates in proline [70]. Although ghrelin (1-27) is present only at a very low level in rat stomach, it is likely 27 and 28 amino acid ghrelin molecules are produced through alternative C-terminal processing of the same ghrelin precursor and that this process may regulate human ghrelin gene maturation. Either ghrelin (1-28) or ghrelin (1-27) are then subjected to a unique post-translational modification: acylation of the hydroxyl group of Ser3. This is most frequently done with an octanoyl group (C8:0) but may also be done with decanoyl (C10:0) and possibly decenoyl moieties (C10:1) [70]. The enzyme responsible for this unique modification remains unknown, but emerging evidence suggests that acylation is at least partially dependent upon nutrient intake. Thus, a recent report showed that acylation of ghrelin can be increased by ingestion of either medium-chain fatty acids (MCFAs) or medium-chain triacylglycerols (MCTs), which are directly used for the acylation of ghrelin [109]. Nevertheless, it remains to be determined whether ingested MCTs directly modulate the Ser3 residue of ghrelin peptide or indirectly stimulate the acyl modification of ghrelin through the induction of an acyl-modifying enzyme.

The purification and characterisation of human ghrelin and analogs from the stomach has been reported and the collected ghrelins have been classified into two groups on the basis of amino acid length [ghrelin (1-28) and ghrelin (1-27)] and into four groups by the type of acylation at Ser3 (nonacylated, octanoylated, decanoylated, and possibly decenoylated). Although the major active form of human ghrelin is a twenty-eight-amino acid peptide with an n-octanoyl modification at Ser3 [ghrelin (1-28)], the ghrelin-derived molecules observed include decanoyl ghrelin (1-28), decenoyl ghrelin (128), octanoyl ghrelin (1-27) and decanoyl ghrelin-(1-27). Moreover, all these molecular forms of ghrelin were found in human plasma as well as in the stomach [70].

Recent evidence suggests that the 66 amino acid tail of wild type proghrelin (29-94) can circulate as a full-length peptide (C-ghrelin) or be processed to smaller peptides, mainly obestatin. Both may have physiological importance.

Pemberton et al. [116] demonstrated the presence of fulllength proghrelin C-terminal peptide (C-ghrelin) in human plasma that circulate at higher concentrations than mature octanoyl ghrelin and are elevated in heart failure, suggesting that it may be bioactive. More recently, Bang et al. [5] suggested that majority of tissue stored and circulating $C$ terminal-derived peptides in mammals are consistent in length with the complete C-terminal sequence of proghrelin and respond to metabolic manipulation, at least in humans, in similar fashion to ghrelin (1-28). They also demonstrated that the tissue distribution of Cghrelin matches that of ghrelin. Therefore, it is probable that the stomach is the main source of circulating C-ghrelin.

In 2005, Zhang et al. [162], by comparative genomic analyses, proposed the existence of a novel peptide derived from $\mathrm{C}$ terminal of proghrelin. This new peptide has been named 'obestatin', based on its appetite-suppressing potential. The structure of obestatin was deduced by amino acid sequencing of a purified 20 residue peptide sequence, combined with mass spectrometry data, to generate a 23 amino acid sequence [proghrelin (53-75)]. On the basis of a C-terminal Gly-Lys motif, amidation of obestatin was assumed and verified as a prerequisite for biological activity [162]. Furthermore, the mass spectrometric data indicated that this peptide may be processed to a 13 amino acid peptide, obestatin (11-23). Further information is required to establish exactly how obestatin (11-23) is formed, although, a recent study indicates that this isoform is indeed biologically active [62]. Obestatin was originally extracted from rat stomach and has subsequently been shown to be a circulating peptide that may fluctuate in the blood like ghrelin 
$[64,164]$. Recently, however, Bang et al. found no evidence for obestatin peptides, circulating as distinct entities in the human and rat circulation, or as a secretable hormone in rat tissues [5]. In this study, specific immunoassays directed to the $\mathrm{N}$ terminus, C-terminus, and mid-region of proghrelin (29-94) all detected the same molecular species of $\mathrm{Mr} \sim 7000$, suggesting that the only forms present were close to the full length 66amino acid C-ghrelin [5]. The reason for this is unclear, but further studies should clarify this issue. Until this happens, we should assume obestatin as an active peptide, as numerous recent studies show, even so it may not exist as an endogenous peptide.

Pre-pro-des-Gln14-ghrelin mRNA is processed in an almost similar manner to preproghrelin, the difference being that it originates a ghrelin peptide devoid of glutamine at position 14, which has a negligible expression in humans, in contrast to other species [70].

As noted previously, Yeh et al. reported the expression of a novel human mRNA transcript designated exon 3-deleted mRNA transcript in breast and prostate cancer [160]. A murine homologue (exon 4-deleted mRNA transcript) has also been identified in a widely range of tissues [75]. Deletion of exon 3 from the preproghrelin transcript results in a frame shift which generates, in addition to the mature ghrelin peptide, a truncated C-peptide with a unique 16-amino-acid peptide tail (COOH-terminal $\Delta 3$ peptide), which begins with a potential peptide cleavage site [Arg-Arg]. It remains to be investigated whether this alternative C-peptide or its potential proteolytic products circulate in human serum, as does the C-ghrelin derived from wild-type (full-length) proghrelin. The preliminary studies indicate that, despite being cleaved from the exon 3-deleted preproghrelin protein, the unique $\mathrm{COOH}$-terminal $\Delta 3$ peptide (RPQPTSDRPQALLTSL) does not influence cell proliferation or have any effect on apoptosis when incubated with prostate cancer cell lines. However, the wide expression of C-ghrelin suggest that it may possess as-yet-unknown physiological functions and support the hypothesis that the generation of the unique C-peptide from the exon 3-deleted variant of proghrelin may also have physiological significance.

\section{Tissue distribution of ghrelin gene-derived peptides}

As stated previously, human ghrelin gene can generate multiple active molecules by alternative splicing and/or extensive post-translational modifications. These molecules can be classified in three main groups: ghrelin and analogs, Cghrelin and obestatin. The former group includes octanoyl ghrelin (1-28), octanoyl ghrelin (1-27), decanoyl ghrelin (1-28), decanoyl ghrelin (1-27), decenoyl ghrelin (1-28), des-acyl ghrelin (1-28) and des-acyl ghrelin (1-27). All these molecular forms of ghrelin were found in human plasma as well as in the stomach, but major active forms seem to be octanoyl ghrelin (1-28) and des-acyl ghrelin (1-28) [70].

Tissue distribution of ghrelin and des-acyl ghrelin seems to be similar. In adult mammals, the tissue with the highest enrichment of ghrelin and des-acyl ghrelin is the stomach with the next highest amounts found in the duodenum, jejunum, ileum, cecum, and colon [69]. In the fetus, however, stomach is not the major source of ghrelin because its ghrelin concentration is very low and only increases after birth. There is increasing evidence that pancreas and lung are alternative sources of ghrelin in the fetus. Pancreas begins to express ghrelin at midgestation and its ghrelin mRNA levels are six to seven times greater than in the fetal stomach [28]. In pancreas, total ghrelin concentrations decreases progressively, after birth, but acylated ghrelin concentrations increases six to seven times [28]. In their study, Nishi et al. [110] reported that the amount of acylated ghrelin in murine stomachs increases gradually during the suckling period to a maximal level at 3 weeks of age and falls sharply after the initiation of weaning. However, the concentration of total ghrelin, which includes des-acyl and all acylated forms of ghrelin peptides with intact $\mathrm{C}$ termini in murine stomach, remains unchanged across this suckling-weaning transition.

In stomach, the cells synthesizing and secreting ghrelin have been identified as the X/A-cells, which are most abundant in the fundus [36]. In the human stomach, the des-acyl:acylated ghrelin ratio was found to be $\sim 2: 1[5,70]$. This indicates that just prior to or upon entry to the circulation, acylated ghrelin is further converted to the nonacylated form, which constitutes $>90 \%$ of total circulating ghrelin (see below) $[5,70]$. Besides the gastrointestinal tissues, ghrelin is also expressed, at lower levels, in many other tissues: hypothalamus, pituitary, adrenal gland, thyroid, breast, ovary, placenta, fallopian tube, testis, prostate, liver, gall bladder, pancreas, fat tissue, human lymphocytes, spleen, kidney, lung, skeletal muscle, myocardium, vein and skin $[55,56]$. Ghrelin produced in tissues other than gastrointestinal tissues may have a range of still-unidentified physiological autocrine or paracrine effects (since GHS-R1a expression is also detected in many of these tissues), but endocrine effects are very unlikely.

C-ghrelin is a peptide derived from the carboxyl terminal of proghrelin (29-94). There may be two types of C-ghrelin: one derived from the wild type proghrelin and one derived from the exon 3 (or exon 4)-deleted proghrelin. The former seems to have the same distribution profile as ghrelin, with highest concentrations observed in the stomach, followed by the duodenum and colon [5]. The expression of the second was detected in prostate cancer cell line lysate, as well as in human stomach carcinoma and normal stomach tissue lysates.

Studies related to tissue expression of obestatin are still limited. Nevertheless, the expression of obestatin was reported in cells of the gastric mucosa, myenteric plexus and perinatal pancreas and in Leydig cells of the testis of rats $[29,44,162]$. A recent study showed that preproghrelin- and obestatin-IR cells were more numerous than ghrelin-IR cells in the rat stomach, suggesting the lack of ghrelin in some X/Alike cells [165]. In the pancreas, obestatin was present in the peripheral part of the islets, with a distribution distinct from that of glucagon-producing A cells, insulin-producing betacells, and cells producing pancreatic polypeptide [165].

\section{Ghrelin gene-derived peptides in circulation}

Two thirds of circulating ghrelin is produced by X/A cells of the oxyntic mucosa of the stomach and most of the remainder 
originates in X/A cells of the small intestine [36]. Using radioimmunoassays with different specificities, Patterson et al. [115] demonstrated that human plasma ghrelin-like immunoreactivity appears to consist almost completely $(>90 \%)$ of des-acyl ghrelin. This is likely due to the shorter half-life of ghrelin than that of des-acyl ghrelin, as plasma ghrelin rapidly disappears from the circulation due to the binding to the GHS-R in the systemic tissues [1]. Deacylation of ghrelin to des-acyl ghrelin, which rapidly occurs in the plasma, is also responsible for the reduced half-life of ghrelin [71].

It is not clear the relationship between the acyl and desacyl ghrelin. Both are present in the human plasma, as well as, in the stomach and both are active, with similar and opposite actions. There are two theories, not mutually exclusive: (1) des-acyl ghrelin could result from an incomplete acylation of the peptide, with both forms being secreted via two differently regulated pathways, (2) des-acyl ghrelin could result from deacylation of ghrelin. In the first theory, des-acyl ghrelin would be an active peptide produced directly from ghrelin gene. In the second theory, des-acyl ghrelin would be produced from ghrelin by deacylation. Regarding the second theory, numerous enzymes were proposed to be responsible for this deacylation. It has been demonstrated that ghrelin is deacylated in human serum by butyrylcholinesterase and platelet-activating factor acetylhydrolase, while in rat serum only carboxylesterase is involved [40]. Paraoxonase may also intervene in ghrelin deacylation, although there is controversy about this issue $[9,40]$. Interestingly, these enzymes are associated with serum lipoproteins, which also participate in the transport of circulating ghrelin (see below). Lysophospholipase I was identified as a ghrelin deacylation enzyme in rat stomach [128]. Importantly, ghrelin deacylation can occur in blood circulation, as well as, during blood collection and subsequent blood handling at room temperature. Therefore, after collection of blood specimens, EDTA and aprotinin should be added and the plasma fraction separated by centrifugation and immediately acidified before freezing at $-70{ }^{\circ} \mathrm{C}$ to ensure stability of acylated ghrelin during storage [71]. In the future, we may use esterases inhibitors to ensure ghrelin stability in human plasma samples.

Various studies suggest that, while des-acyl ghrelin circulates as a free peptide, the majority of circulating acylated ghrelin is bound to larger molecules, particularly lipoproteins $[9,40,115]$. By reverse phase chromatography followed by radioimmunoassays, Vriese et al. found that ghrelin is associated with triglyceride-rich lipoproteins (TRL), high-density lipoproteins (HDL), very highdensity lipoproteins (VHDL), and to some extent LDL. The increased hydrophobicity of the acyl side chain of active ghrelin may cause it to bind to larger plasma proteins in blood [40].

As stated above, C-ghrelin derived from wild-type ghrelin was detected in human circulation, and its serum levels were elevated in patients with heart failure [116]. It remains to be investigated whether the alternative C-peptide or its potential proteolytic products from exon 3-deleted preproghrelin circulate in human serum, as does the C-peptide derived from wild-type (full-length) proghrelin.

\section{Factors regulating differential expression of ghrelin genes products}

The factors that regulate the differential expression of ghrelin gene-derived peptides remain largely undetermined. Nevertheless, some studies have provided some insight regarding this issue.

Fasting seems not to influence obestatin, while increasing ghrelin, des-acyl ghrelin and C-ghrelin in the same proportion $[5,162]$. Feeding also seems to decrease ghrelin, des-acyl ghrelin and C-ghrelin [5,162]. However, postprandial acylated ghrelin levels fall more quickly than total ghrelin. This may reflect changes in secretion of acylated ghrelin and/or the des-acylation of acylated ghrelin [5]. Effects of feeding on obestatin plasma levels are controversial with some studies suggesting no effect and others suggesting a negative effect $[64,5,162]$.

Chronic positive balance may alter ghrelin:obestatin ratio. Guo et al. showed that the ratio of pre-prandial ghrelin to obestatin was higher in obese compared with normal weight controls even after adjustment for gender and age. Body mass index was positively correlated with and a significantly independent determinant of the pre-prandial ghrelin:obestatin ratio [63].

Ingestion of either medium-chain fatty acids (MCFAs) or medium-chain triacylglycerols (MCTs) increased the stomach concentrations of acylated ghrelin without changing the total (acyl- and des-acyl-) ghrelin amounts, suggesting that ghrelin acylation is at least partially dependent upon nutrient intake [109].

There may also be a developmental regulation of ghrelin gene-derived peptides expression. Chanoine et al. showed that, in plasma, total ghrelin concentrations decreased abruptly after birth, contrasting with a 3 -fold increase in the concentration of acylated ghrelin [28].

Finally, Yoshimoto et al. [161] suggested that kidneys can modulate the ratio of the different ghrelin gene-derived peptides. Des-acyl ghrelin plasma levels, but not ghrelin levels, were significantly correlated with the serum creatinine level and were increased 2.8-fold in patients with end-stage renal disease compared with those in patients with normal renal function. Bilateral nephrectomy in mice caused marked increase in the des-acyl ghrelin plasma levels without significant changes in the ghrelin levels and ghrelin mRNA level in the stomach, which is the main site of ghrelin production. These findings suggest that the kidney is an important site for clearance and/or degradation of desacyl ghrelin.

\section{Receptors of ghrelin gene-derived products}

The most well investigated ghrelin receptor, GHS-R1, has two variants resulting from alternative processing of pre-mRNA of the same gene that are designated type $1 \mathrm{a}$ and type $1 \mathrm{~b}$ [56]. Like GHS-R1a, GHS-R1b has a widespread expression but, unlike GHS-R1a, does not bind ghrelin or synthetic GHS and it is not clear whether it is functional [56].

GHS-R1a is highly expressed in the hypothalamus and pituitary, consistent with ghrelin's observed action on the pituitary, and its role in the control of appetite, food intake and 
energy balance [72]. Interestingly, however, GHS-R1a expression has also been reported in areas of the CNS that affect biological rhythms, mood, cognition, memory, and learning, such as the hippocampus, pars compacta of the substancia nigra, ventral tegmental area, dorsal and medial raphé nuclei and Edinger-Westphal nucleus and pyriform cortex [62]. Moreover, a ghrelin-receptor transcript product is also found in the vagal nodose ganglion, whose activation may mediate many ghrelin effects [17] and multiple peripheral organs, such as the stomach, intestine, pancreas, thyroid, gonads, adrenal, kidney, heart and vasculature, bone, various tumors and cells lines express GHS-R1a [56,91]. These data are in agreement with the rising spectrum of actions of ghrelin. Recent experiments performed in GHS-R1a knockout mice showed that GHS-R1a is essential for the stimulatory effects of ghrelin on GH secretion, as well as, its orexigenic effects [135]. Acylation at Ser3 is essential for GHS-R1a activation [11,100]. All acyl-modified ghrelin analogs seem to have the same potency to induce an increase of $\mathrm{Ca}^{2+}$ concentration in the GHS-R-expressing cells and to stimulate GH release in anaesthetised rats [70]. In addition, short peptides encompassing the first four or five residues of ghrelin were found to functionally activate GHS-R about as efficiently as the full length ghrelin and only the segment Gly-Ser-Ser-(n-octanoyl)Phe appeared to constitute the 'active core' required for agonist potency at human GHS-R [11].

Many studies have demonstrated that ghrelin binds and is active on some cells lines devoid of GHS-R1a and that ghrelin and other GHS show different binding and activities in the same system, reinforcing the idea that GHS-R1a is not the sole receptor for ghrelin and/or GHS. Based on binding and functional studies, the list is continuously growing and actually includes receptors for des-acyl ghrelin, receptors other than GHS-R1a for ghrelin, common receptors for ghrelin and des-acyl ghrelin with the same or antagonistic effects in response to these two ligands and even receptors with specific binding for peptidyl GHSs (hexarelin) [18]. Only the last one has been characterized. In the coronary vasculature, this receptor has been identified as CD36, a multifunctional B-type scavenger receptor [12].

Des-acyl ghrelin does not bind GHS-R1a, as acylation at Ser3 is essential for GHS-1a activation. Therefore, its effects should be mediated by other receptors. As noted above, there may be receptors specific for des-acyl ghrelin and receptors common to acyl and des-acyl ghrelin, although, none of these have been characterized yet. Several recent in vitro studies have shown that des-acyl ghrelin exhibits biological activities on cell proliferation and metabolism and binds to cell membranes of cardiomyocytes, adipocytes, prostatic and skeletal muscle cells $[4,24,48,104]$.

Obestatin was initially reported to be the endogenous ligand of the orphan receptor $G$ protein-coupled receptor 39 (GPR39), a GTP-binding protein-coupled receptor that shares homology with GHS-R1a [162]. However, recent reports indicate that obestatin is unlikely to be the endogenous ligand for GPR39 based on the lack of specific binding on GRP39 receptor expressing cells and the absence of signal transduction pathway activation $[30,89]$. In contrast, the potency and efficacy of $\mathrm{Zn}^{2+}$ in activating signalling pathways indicates that this metal ion could be a physiologically relevant agonist or modulator of GPR39 [68]. Thus, we still wait for the identification of the obestatin receptor(s).

\section{Effects of ghrelin gene-derived products}

\subsection{GH secretion}

Table 1 summarizes the differences between physiological actions of ghrelin, des-acyl ghrelin and obestatin.

Ghrelin possesses a strong and dose-related GH-releasing effect, both in vitro and in vivo, in humans and animals [97]. The ghrelin GH-releasing effect seems to result from ghrelin binding to GHSR-1a on somatotrophic cells at the pituitary [97], ghrelin-induced activation of GHRH-neurons and inhibition of somatostatin neurons at the hypothalamus [119] and ghrelininduced vagal afferent activation [17].

Under normal situations des-acyl ghrelin does not influence GH secretion, as it cannot bind GHS-R1a. However, in transgenic mice over expressing des-acyl ghrelin, it may modulate the GH-IGF-I axis (reducing responses of GH to administered ghrelin) and results in a small phenotype in transgenic mice [2].

Most studies showed that neither intravenous nor intracerebroventricular administration of obestatin affects the secretion of GH in rats $[13,111,125,158,162]$. Nevertheless, a recent study showed that obestatin, in some conditions, can inhibit exogenous ghrelin action on GH release [164]. It remains to be determined whether obestatin modulates endogenous ghrelin actions.

\subsection{Appetite and body weight}

Several studies have shown that ghrelin regulates appetite and body weight. Short-term fasting results in pre-prandial rise in ghrelin levels and hunger scores corresponded to ghrelin levels in a study involving subjects initiating meals voluntarily without time- and food-related clues [35]. This implicates that ghrelin might be an important factor for meal initiation as, in animals and humans, infusion of ghrelin stimulates appetite and increases spontaneous food intake $[90,156]$. Recent studies have clarified the cellular mechanism underlying the orexigenic effect of ghrelin. By activating vagal afferents [155] or via the bloodstream [67], the signal reaches the arcuate nucleus of the hypothalamus. Here, neurones containing the orexigenic peptides neuropeptide $\mathrm{Y}$ and agouti related peptide are activated, while neurones containing the anorexigenic peptides cocaine and amphetamine related transcript and pro-opiomelanocortin are inhibited [31]. The arcuate neurones project to other nuclei, among them orexin containing neurones in the lateral hypothalamic area, to stimulate appetite [146]. Recent data show that central ghrelin (ghrelin secreted by hypothalamic neurones) could be of importance in the orexigenic effect of ghrelin [34].

Beyond an orexigenic effect, ghrelin can also regulate body weight in long-term. Ghrelin responds to changes in body weight: levels of ghrelin increase after weight loss and go down after weight gain [35]. Long-term ghrelin administration promotes weight gain, not only by stimulating food intake, but 
Table 1 - Effects of ghrelin gene-derived products

\begin{tabular}{|c|c|c|c|}
\hline Effect & Ghrelin & Des-acyl ghrelin & Obestatin \\
\hline \multicolumn{4}{|l|}{ Endocrine } \\
\hline GH & $\uparrow$ & $\leftrightarrow \downarrow$ & $\leftrightarrow \downarrow$ \\
\hline ACTH, TSH, AVP & $\uparrow$ & $\leftrightarrow$ & $\leftrightarrow$ \\
\hline Appetite/body weight & $\uparrow$ & $\downarrow \uparrow$ & $\downarrow \leftrightarrow$ \\
\hline Water intake & $\downarrow$ & $\leftrightarrow$ & $\downarrow$ \\
\hline \multicolumn{4}{|l|}{ Metabolism } \\
\hline \multicolumn{4}{|l|}{ Glucose } \\
\hline Glucose sensing & $\downarrow$ & nd & nd \\
\hline Insulin secretion & $\downarrow \uparrow$ & $\downarrow$ & $\downarrow \uparrow \leftrightarrow$ \\
\hline Insulin action & $\uparrow$ (periphery)/ $\downarrow$ (liver) & $\leftrightarrow$ (periphery)/\ (liver) & nd \\
\hline Glucose production & $\uparrow$ & $\downarrow$ & nd \\
\hline \multicolumn{4}{|l|}{ Lipid content } \\
\hline Liver & $\uparrow$ & nd & nd \\
\hline Muscle & $\downarrow$ & nd & nd \\
\hline Adipocyte & $\uparrow$ & $\uparrow$ & nd \\
\hline \multicolumn{4}{|l|}{ Reproduction } \\
\hline LH secretion & $\downarrow$ & $\downarrow$ & nd \\
\hline Embryogenesis & $\downarrow$ & nd & nd \\
\hline Testosterone secretion & $\downarrow$ & nd & nd \\
\hline Spermatogenesis & $\downarrow$ & nd & nd \\
\hline Follicle survival and action & $\uparrow$ & nd & $\uparrow$ \\
\hline \multicolumn{4}{|l|}{ Gastrointestinal } \\
\hline Exocrine secretion & $\uparrow \downarrow \leftrightarrow$ (stomach) $/ \uparrow$ (pancreas) & $\leftrightarrow$ (stomach) & $\uparrow($ pancreas) \\
\hline Epithelial protection & $\uparrow$ & nd & nd \\
\hline Motility & $\uparrow$ (stomach and colon) & $\downarrow$ (stomach)/↔ (jejune) & $\downarrow$ (stomach and jejune)/↔ \\
\hline \multicolumn{4}{|l|}{ Cardiovascular } \\
\hline \multicolumn{4}{|l|}{ Vascular dymanics } \\
\hline Macrovessels dilation & $\uparrow$ (systemic) $/ \downarrow$ (coronary) & $\uparrow$ (systemic) & nd \\
\hline Microvessels dilation & $\uparrow$ & nd & nd \\
\hline Endothelium function & $\uparrow$ & nd & nd \\
\hline Heart function & $\uparrow$ & $\uparrow$ & $\leftrightarrow$ \\
\hline Cell proliferation & $\uparrow \downarrow$ & $\uparrow \downarrow$ & $\uparrow$ \\
\hline \multicolumn{4}{|l|}{ Imune function } \\
\hline Immune cell production & $\uparrow$ & $\leftrightarrow$ & nd \\
\hline Cytokine production & $\downarrow$ & $\leftrightarrow$ & nd \\
\hline Neutrophil action & $\downarrow$ & nd & nd \\
\hline \multicolumn{4}{|l|}{ Bone } \\
\hline Osteoblast production & $\uparrow$ & $\uparrow$ & $\leftrightarrow$ \\
\hline Osteoblast action & $\uparrow$ & nd & $\leftrightarrow$ \\
\hline Sleep & $\uparrow$ & $\leftrightarrow$ & $\uparrow$ \\
\hline Memory & $\uparrow$ & $\leftrightarrow$ & $\uparrow$ \\
\hline Anxiety & $\uparrow$ & $\leftrightarrow$ & $\downarrow$ \\
\hline \multicolumn{4}{|l|}{ Iris muscle relaxation } \\
\hline Sphincter & $\uparrow$ & $\uparrow$ & nd \\
\hline Dilator & $\uparrow$ & $\leftrightarrow$ & nd \\
\hline
\end{tabular}

$(\uparrow)$, stimulation; ( $\downarrow)$, inhibition; $(\leftrightarrow)$, no effect; nd, effect not determined.

also by regulating other aspects of energy homeostasis. Indeed, ghrelin increases the preference for dietary fat [129] and directly promotes adipogenesis [144]. It can also decrease lipolysis [104], adipocyte apoptosis [76], energy expenditure and sympathetic nervous system activity [159], body tem- perature [148], proinflammatory cytokine production [41] and locomotor activity [141].

Depending upon the experimental condition, des-acyl ghrelin has been reported to be able to either inhibit $[3,32,99]$ or stimulate [147] food intake. Nevertheless, most available data 
suggest a negative association between des-acyl ghrelin and food intake. The food-inhibiting effect seems to be specific for central administration and mediated by increased gene expression of cocaine and amphetamine regulated transcript and urocortin on the paraventricular nucleus and the arcuate nucleus in the hypothalamus [3]. In addition, des-acyl ghrelin over expressing mice exhibited a decrease in body weight and fat pad mass weight accompanied by moderately decreased linear growth, suggesting that, in contrast to ghrelin, des-acyl ghrelin generates a negative energy balance [3].

There is great controversy about the effects of obestatin on food intake with some studies suggesting that it may inhibit food intake and suppress body weight under basal and ghrelin-stimulated conditions $[13,61,86,162,164]$ and others suggesting no effect $[58,111,127,131]$. Recent studies have partially clarified this issue. In one of these studies, intraperitoneal obestatin suppressed food intake and body weight gain in rodent in an U-shaped dose-response relationship. This relationship may explain the difficulties in reproducing the effects of obestatin on feeding reported by some groups [86]. In the other study, intracerebroventricular administration of obestatin inhibited water drinking in ad libitum-fed and watered rats, and in food- and water-deprived animals [125]. The effects on water drinking preceded and were more pronounced than any effect on food intake, and did not appear to be the result of altered locomotor/behavioral activity. Thus, it appears that obestatin possess biologic activity but that the effect on food intake may be secondary to an initial action in inhibiting thirst phenomenon referred to by some authors as dehydration anorexia [125]. Interestingly, ghrelin also seems to have an antidipsinogenic effect. Intracerebroventricular injection of ghrelin inhibited water intake in chicks under both ad libitum and 17-h water deprived drinking conditions. On the other hand, des-acyl ghrelin does not reduce water intake [138].

\subsection{Metabolism}

\subsubsection{Glucose metabolism}

Ghrelin has been implicated in the regulation of glucose homeostasis, by modulating sensitivity of glucose-sensing neurones in the brain, insulin secretion and action and hepatic glucose production. Recently, it was demonstrated that ghrelin can inhibit the activity of the glucosensing neurons (glucose-inhibited and glucose- excited neurons) in the dorsal vagal complex of rats $[118,152]$. Depending upon the experimental condition, ghrelin has been reported to be able to either inhibit or stimulate insulin secretion in animals and humans [14]. Nevertheless, most available data suggest a negative association between systemic ghrelin and insulin levels, with ghrelin inhibiting insulin secretion both in vitro and in most human or animal studies [14]. This effect may be mediated by GHS-R1a whose expression was detected in animal and human endocrine pancreas [56]. In addition, ghrelin may also regulate some peripheral effects of insulin. Thus, ghrelin hampers insulin's capacity to suppress endogenous glucose production, whereas it reinforces the action of insulin on glucose disposal in mice [66], inhibits secretion of the insulin-sensitizing protein adiponectin from adipocytes [112] and stimulates secretion of the counter-regulatory hormones, including GH, cortisol and epinephrine [97] and possibly glucagon [124].

Acute ghrelin administration in humans increases plasma glucose levels [14]. The hyperglycaemic effect of ghrelin may result not only from the endocrine effects of ghrelin, but also from ghrelin's direct effects on hepatocytes, where it has already been shown to be able to modulate glycogen synthesis and gluconeogenesis, stimulating hepatic glucose production [52,105].

Des-acyl ghrelin can also regulate glucose metabolism. Recently, it was demonstrated that at a ten times higher concentration than acyl ghrelin (corresponding to the ratio of the two peptides in circulation), des-acyl ghrelin abolished the effects of acyl ghrelin on insulin secretion from mouse and rat pancreas isolated islets [120]. In addition, it hampers insulin's capacity to inhibit endogenous glucose production, but does not affect glucose disposal. The restraining effects of des-acyl ghrelin and ghrelin on hepatic insulin action are abolished by simultaneous administration of both peptides [66,114]. Finally, des-acyl ghrelin inhibits glucose output by primary hepatocytes and counteracts the stimulatory effect of ghrelin on glucose release. These actions must be mediated by a receptor other than GHS-R1a, and apparently, we must consider ghrelin and des-acyl ghrelin as separate hormones that can modify each other actions on glucose handling [52].

Data regarding effects of obestatin on insulin secretion are limited and controversial as stimulation [60], inhibition [120], and lack of effect [61] have been reported. Further studies are necessary to clarify this issue and the effects of obestatin on glucose-sensing neurones, insulin action and hepatic glucose production.

\subsubsection{Lipid metabolism}

Ghrelin has also been implicated on the regulation of lipid metabolism, with effects in the liver, skeletal muscle and adipose tissue. In the liver, ghrelin induced lipogenic patterns of gene expression and triglyceride content, whereas the activity of the stimulator of fatty acid oxidation, AMPK, was reduced [6]. In the gastrocnemius muscle, ghrelin reduced triglyceride content, increased mitochondrial oxidative enzyme activities and increased mRNA encoding uncoupling protein 2, independent of changes in expression of fat metabolism genes and phosphorylation of AMPK [6]. Peroxisome proliferator activated receptor $\gamma$, which, upon activation, reduces muscle fat content, was also selectively increased in skeletal muscle [6]. Thus, ghrelin favours triglyceride deposition in the liver over the skeletal muscle. Moreover, ghrelin also acts directly on adipocytes. Ghrelin stimulates lipogenesis in differentiated adipocytes in vitro and in vivo, by increasing the levels of peroxisome proliferator-activated receptor $\alpha$ and the insulin-induced glucose uptake [114,144], antagonizes lipolysis, reducing isoproterenol-stimulated lipolysis in vitro [104] and stimulates the proliferation and differentiation of preadipocytes [76].

Data regarding effects of des-acyl ghrelin on lipid metabolism are scarce. Similar to acyl ghrelin, des-acyl ghrelin promotes lipogenesis directly in vivo [144] and inhibits isoproterenol-induced lipolysis in rat adipocytes [104] by a mechanism independent of GHS-R1a. The effects of obestatin on lipid metabolism have not yet been determined. 


\subsection{Reproduction}

To date, expression of ghrelin and its receptor have been documented in various reproductive organs, such as placenta, testis Leydig cells, rat ovary, mouse embryo and endometrium, suggesting that ghrelin may have a role on the regulation of reproductive function [20,53,54,80,142]. Indeed, available data suggest that ghrelin regulates several aspects of reproductive physiology, at least partially, in a paracrineautocrine manner.

At the pituitary, ghrelin suppress different aspects of pulsatile LH secretion, in animals and in healthy humans, both in vivo and in vitro conditions $[47,88]$. Of note, ghrelin is also able to decrease GnRH release ex vivo by hypothalamic explants from ovariectomized female rats and decreases GnRH-induced LH release ex vivo by pituitaries from prepubertal animals and adult cyclic female rats, at different stages of the estrous cycle [47]. This observation, together with its reported effects on LH pulsatilty, strongly suggests a major central (hypothalamic) site of action for the inhibitory effects of ghrelin on the gonadotropic axis. Noteworthy, the actions of ghrelin on FSH secretion in vivo remain less well characterized.

Besides central actions on the reproductive axis, several lines of evidence indicate that ghrelin is also expressed and conducts specific biological effects directly at the gonadal level; a phenomenon which illustrates the multifaceted mode of action of ghrelin in the control of the gonadotropic axis.

An isolated study showed that, in cultured whole porcine follicles, treatment with ghrelin resulted in an increase in estradiol secretion, aromatase activity and a decrease in caspase-3 activity [121]. In males, ghrelin has an inhibitory role, decreasing the expression of the stem cell factor (SCF) gene, a key mediator of spermatogenesis and a putative regulator of Leydig cell development [7] and inhibitor of hCGand cAMP-stimulated testosterone secretion in vitro [142].

Ghrelin may also regulate preimplantation embryo during its development. Addition of ghrelin to culture media inhibits the development of mouse preimplantation embryos [80]. Recently, it was demonstrated that ghrelin exerts an inhibitory effect on contractility of dissected myometrial strips suspended under isometric conditions, undergoing spontaneous and oxytocin-induced contractions [65]. Overall, these findings show a predominantly inhibitory role of ghrelin in reproductive function.

Concerning des-acyl ghrelin, a recent study involving acute administration to adult male rats in freely moving conditions, as well as chronic infusions, demonstrated that des-acyl ghrelin is able to mimic the inhibitory effects of acylated ghrelin on $\mathrm{LH}$ secretion [98]. Likewise, repeated administration of des-acyl ghrelin was as effective as acylated ghrelin in inducing a partial suppression of the activation of the gonadotropic axis at puberty, as evidenced by similar decreases in serum LH levels and percentages of balanopreputial separation in ghrelintreated groups [98].

Data regarding obestatin effects on reproductive function are very limited. A recent study demonstrated that obestatin may directly control porcine ovarian granulosa cells functions, stimulating proliferation and apoptosis of theses cells and the secretion of progesterone [102].

\subsection{Gastrointestinal function}

Available data suggest that ghrelin affects many aspects of GI function, including exocrine secretion, epithelial protection and motility.

Results regarding the effects of ghrelin on gastric acid secretion are equivocal, as stimulation (probably via vagal pathways stimulating parietal cells) [157], inhibition [131], and lack of effect [43] have been reported. It was suggested that conflicting data may reflect the presence of both stimulatory and inhibitory pathways, and that experimental conditions and models may determine how they balance out. The stimulatory action of ghrelin on gastric secretion may be important in preparing the stomach to process food. Ghrelin is also able to stimulate pancreatic protein secretion via central pathways [94].

Ghrelin may also stimulate cell proliferation and differentiation of the gastrointestinal epithelium. Indeed, a gastroprotective effect has been demonstrated in various models, which seems to depend mainly on vagal activity, sensory nerves and hyperaemia mediated by nitric oxide synthase-nitric oxide (NOS-NO) and cyclooxygenase-prostaglandin systems $[15,16]$. The protective effect has also been demonstrated in experimental colitis [57]. A recent study showed that, both intraperitoneally and centrally administered, ghrelin suppresses mucosal intestinal apoptosis in fasting rats [113].

Structural relationships between ghrelin and motilin, lead to evaluation of the motility effects of ghrelin. Indeed, it was demonstrated that ghrelin, like motilin, induces the migrating motor complex (MMC) and accelerates gastric emptying, both in humans and rodents $[139,140]$. Also, ghrelin seems to accelerate colonic motility [130]. Prokinetic actions of ghrelin are mediated by the cholinergic system, via central mechanisms and probably by the myenteric plexus $[38,50]$.

Des-acyl ghrelin does not seem to influence gastric secretion [43,132]. Regarding to motility, des-acyl ghrelin inhibits gastric emptying without altering small intestinal transit $[3,32]$. Peripheral des-acyl ghrelin may induce this function by direct activation of brain receptor (CRF 2) by crossing the blood-brain barrier but not by the activation of vagal afferent pathways [32]. The effects on cell proliferation and differentiation of the gastrointestinal epithelium were not yet determined.

Recently, obestatin was demonstrated to stimulate the secretion of pancreatic juice enzymes through a vagal pathway in anaesthetized rats [78]. As with the effects of obestatin on regulation of food intake, its effects on gastrointestinal motility are involved in great controversy with most studies reporting no effect $[8,39,58]$ and others reporting a negative effect (in gastric and jejunal motility) under basal and ghrelin-stimulated conditions [162]. Further studies should clarify this issue and its effects on gastric exocrine secretion and epithelial protection.

\subsection{Cardiovascular function}

Numerous studies suggest that ghrelin has a wide array of cardiovascular activities.

Regarding the macrocirculation, the vasoactive effects of ghrelin depend on the vascular territory. In the systemic 
circulation, ghrelin has a vasodilatory effect that is endothelium-independent $[82,149]$ and involves peripheral and central mechanisms [95]. Indeed, intravenous administration of ghrelin in humans causes a significant decrease in mean arterial pressure, but does not change heart rate [106]. By contrast, ghrelin increases coronary perfusion pressure in rat hearts perfused using the Langendorf system and significantly increases pressure-induced myogenic tone in coronary arterioles [117]. In the microcirculation, ghrelin increases vascular flow, and this action may affect other physiological functions of ghrelin [145].

Ghrelin is also able to improve endothelial function by inhibiting basal and TNF- $\alpha$-induced chemotactic cytokine production, increasing nitric oxide bioactivity and inhibiting angiotensin II-induced migration of human aortic endothelial cells $[93,123,143]$.

Salutary cardiotropic effects of ghrelin have been demonstrated in various experimental models. These may result not only from an increase in $\mathrm{GH}$, appetite and vasodilation, and decrease in cytokine production, but also from direct effects of ghrelin on cardiomyocytes. In vitro, ghrelin decreases inotropism [10,133] and lusitropism [133], inhibits apoptosis of cardiomyocytes [4], improves myocardial function during ischemia/reperfusion and isoproterenol-induced injury [27,92] and reduces infarct size [49]. In healthy volunteers [106] and patients with chronic heart failure [107], ghrelin decreases systemic vascular resistance, which results in increased cardiac output as shown by increased cardiac index and stroke-volume index.

Compared with ghrelin, des-acyl ghrelin shows similar endothelium independent vasodilator potency [82,149]. Like ghrelin, des-acyl ghrelin decreases inotropism [10], inhibits apoptosis of cardiomyocytes [4] and has cardioprotective effects on myocardial injury induced by isoproterenol in rats [92].

An isolated study found no effect of obestatin on cardiomyocyte viability and metabolism [73]. Additional studies are needed to evaluated effects of obestatin on vascular and endothelial functions.

\subsection{Cellular proliferation}

Recent evidence supports a role for ghrelin in the regulation of proliferation, apoptosis and differentiation of various normal and neoplastic cells lines, via mechanisms dependent and independent of GHS-R1a. Ghrelin stimulates the proliferation and inhibits apoptosis of the H9c2 cardiomyocyte cell line [4], human adrenal zona glomerulosa cells [101], preadipocytes [76], osteoblastic cells [96] and pancreatic beta-cells [59] and rat fetal spinal cord [126] and skin cells [108]. Thus, peripheral actions of ghrelin result not only from modulation of function, but also from regulation of survival/proliferation of target cells. Additionally, ghrelin stimulates differentiation of osteoblastic cells [96] and C2C12 skeletal myoblasts [48].

Evidence that ghrelin and ghrelin/GHS receptors are coexpressed in several tumors and related cell lines suggests that the ghrelin system is likely to play an important autocrine/ paracrine role in neoplasms development.

In vitro experiments demonstrated that ghrelin may stimulate or inhibit the proliferation of several human tumor cell lines. An antiproliferative effect of ghrelin was shown in small cell [25], breast [23], thyroid [151] and prostate carcinoma cell lines [24], while a proliferative effect was shown in hepatoma [105], prostatic carcinoma [74] and pancreatic carcinoma cell lines [45]. Additionally, ghrelin may also regulate neoplasm proliferation by exerting an inhibitory effect on angiogenic factors. In assays developed with endothelial cells (HUVEC cells), ghrelin inhibited FGF-2induced cell proliferation, as well as, Matrigel tube formation [33].

Des-acyl ghrelin shares with ghrelin many effects on regulation of cell proliferation, apoptosis and differentiation. Des-acyl promotes cell survival and inhibits apoptosis of H9c2 cardiomyocyte cell line [4] and in pancreatic beta-cells [59]. In vitro, des-acyl ghrelin induces proliferation of rat fetal spinal cord [126] and skin cells [108]. Moreover, des-acyl ghrelin promotes differentiation and fusion of C2C12 skeletal myoblasts [48]. Like ghrelin, des-acyl ghrelin inhibits proliferation and increases apoptosis of small cell carcinoma cell lines [25] and exerts different effects on cell proliferation in prostate carcinoma cell lines [24].

Obestatin may also be able to influence cell proliferation and apoptosis. It was demonstrated that obestatin induces cell proliferation in primary cultures of human retinal epithelial cells by MEK/ERK 1/2 phosphorylation [19] and promotes human islets cells survival through cAMP increase and involvement of AC/CAMP/PKA signalling [60].

\subsection{Immunomodulation}

GHSR mRNA is expressed in several lymphoid organs [56] and in various leukocyte subsets including $\mathrm{T}$ and $\mathrm{B}$ cells, monocytes [41], suggesting that ghrelin might play some role in the generation and/or control of immune interactions. In fact, various studies demonstrated that ghrelin may modulate immune cell proliferation and activation and secretion of proinflamatory cytokines.

Chronic administration of a ghrelin mimetic to old mice stimulated growth, differentiation and cellularity of the thymus, in addition to increasing T-cell production [85]. This resulted in an enhanced resistance to the initiation of neoplasms and subsequent metastasis in animals inoculated with lymphoma cells and an improved thymic engraftment in bone marrow transplant recipients [85].

In vitro studies showed that ghrelin inhibited ROS generation by human PMN in a dose-dependent manner [46]. Interestingly, ghrelin ameliorates pancreaticobiliary inflammation and associated remote organ injury induced by pancreaticobiliary obstruction, by inhibiting neutrophil action [79].

Ghrelin also modulates the production of proinflammatory cytokines. Recently, it has been shown that ghrelin and the GHS-R are found in human $\mathrm{T}$ cells and monocytes, where ghrelin specifically inhibited chronic, LPS- and leptin-induced synthesis of proinflammatory anorectic cytokines such as leptin, interleukin $1 \beta$ (IL-1 $\beta$ ), IL- 6 and tumor necrosis factor $\alpha$ $($ TNF- $\alpha$ ) $[26,41,93]$. These data have established a novel role for ghrelin in immune cell function as a negative regulator of inflammatory cytokine expression induced by cell activation by antigen, mitogens, or leptin. 
On the contrary, des-acyl ghrelin does not influence immune function $[42,93]$, while effects of obestatin on immune system were not yet determined.

\subsection{Bone physiology}

Recent studies indicate that ghrelin is also involved in the regulation of bone growth and metabolism as one of its peripheral effects. It has been demonstrated that primary osteoblasts, as well as osteoblastic cell lines of various species, express GHS-R1a [96]. Evidence was also provided that ghrelin treatment directly stimulates fetal rat calvarial osteoblastic cells proliferation and differentiation, alkaline phosphatase activity and calcium accumulation in the matrix primary [96]. In addition, ghrelin increased bone mineral density of both normal and GH-deficient rats [51]. These observations show that ghrelin directly stimulates bone formation.

Data regarding effects of des-acyl ghrelin and obestatin on bone physiology are very limited. A recent study demonstrated des-acyl ghrelin stimulates human osteoblasts proliferation in the absence of GHS-R1a [37]. Unlike ghrelin, obestatin does not exert any relevant activity in chondrocytes [87].

\subsection{Other effects}

Numerous other effects have been attributed to ghrelin. The continuously increasing list includes stimulation of prolactin, ACTH, AVP [103,106], promotion of slow-wave sleep [154], memory retention and anxiety-like behavior [21] and stimulation of milk secretion [108]. Recently, we have reported that ghrelin is expressed in the iris and induces relaxation of iris sphincter and dilator muscles [122].

Des-acyl ghrelin does not influence sleep, memory, behavior nor milk secretion [21,108,154]. Relaxing effects of des-acyl ghrelin in iris sphincter muscle were similar to those of ghrelin, while in dilator muscle, des-acyl ghrelin did not significantly alter active tension and the relaxing effect of ghrelin was blunted by GHSR-1a blockage [122].

Neither intravenous nor intracerebroventricular administration of obestatin affects the secretion of prolactin, TSH and ACTH in rats $[13,111,125,158,162]$. On the other hand, a recent report provides evidence indicating that obestatin effects are functionally opposite on anxiety to that of ghrelin, while both these related peptides increase memory retention [22]. Recently, it was demonstrated that obestatin has also a sleep-promoting effect when administrated centrally but not peripherally [137].

\section{Ghrelin and GHS-R knockout mice}

Recently, ghrelin (ghrelin-/-) and GHS-R (GHS-R-/-) knockout adult mice were generated to study the importance of GHS-R to ghrelin actions and the biologically relevant actions of the ghrelin/GHS-R system $[134,135,136]$. GHS-R-/- mice are refractory to the stimulatory effects of ghrelin on $\mathrm{GH}$ release and appetite, confirming that the GHS-R is a physiologically relevant ghrelin receptor. Additionally, comparisons have revealed no major phenotypic differences and only modest differences between ghrelin-/- or GHS-R-/- mice and wild type mice. Deletions of ghrelin or the GHS-R impairs neither growth nor appetite. Moreover, deletion of ghrelin or the GHS$\mathrm{R}$ in these adult mice does not prevent diet-induced obesity or prevent weight gain after weight loss. On the other hand, under caloric restriction, the weight loss of ghrelin-/- or GHS$\mathrm{R}-/$ - mice was identical to wild type mice, but blood glucose levels were significantly lower. Ablation of ghrelin in mice increased glucose-induced insulin secretion, and improved peripheral insulin sensitivity, suggesting that adult congenic ghrelin-/- and GHS-R-/- mice are not resistant to dietinduced obesity, but under conditions of negative energy balance show impairment in maintaining glucose homeostasis. These results support the hypothesis that the primary function of ghrelin in adult mice is to modulate glucose sensing and insulin sensitivity, rather than directly regulate energy intake and energy expenditure. Nevertheless, although ghrelin or GHS-R1a knockout animals have a similar appearance to wild type animals, suggesting that ghrelin does not play a significant role in determining growth or appetite, the presence of compensatory mechanisms cannot be ruled out as an explanation for these findings.

\section{Conclusion}

Since its discovery in 1999, there has been a tremendous interest on ghrelin, so that it has become one of the most important subjects of scientific research. This is due to the ubiquity of ghrelin and receptors of ghrelin and the multiplicity of physiological functions of ghrelin. Current evidence shows ghrelin affects GH release, food intake, energy and glucose homeostasis, gastrointestinal, cardiovascular, pulmonary and immune function, cell proliferation and differentiation and bone physiology. The discovery of des-acyl ghrelin and obestatin as bioactive products of the ghrelin gene, produced by alternative splicing or extensive post-translational modifications, brought even more attention to this novel endocrine system. Des-acyl ghrelin and obestatin have already proven to be active, influencing many of the physiological functions modulated by ghrelin, with similar and opposite effects. Thus ghrelin, des-acyl ghrelin and obestatin may be part of a system with multiple effector elements, which not only may have opposite actions but may regulate the action of each other. Nonetheless, many questions remain unsolved:

1. Is obestatin an endogenous peptide with biological activity? And if it is active, what are its receptors?

2. Is C-ghrelin a distinct peptide with biological activity? And if it is active, what are its receptors?

3. Which is the relation between acylated and non-acylated forms of ghrelin?

4. What are the receptors of des-acyl ghrelin?

5. How is the differential expression of ghrelin gene products regulated?

6. What are the enzymes responsible for preproghrelin processing?

7. What are the enzymes responsible for acylation/deacylation of ghrelin? How is this process regulated? 
8. What are the differences between physiological and pharmacological actions of ghrelin?

These questions should be answered in the near future. The answers will help us to better understand the physiological, pathological and therapeutic roles of this novel endocrine system.

\section{R E F E R E N C E S}

[1] Akamizu T, Shinomiya T, Irako T, Fukunaga M, Nakai Y, Nakai Y, et al. Separate measurement of plasma levels of acylated and desacyl ghrelin in healthy subjects using a new direct ELISA assay. J Clin Endocrinol Metab 2005; 90:6-9.

[2] Ariyasu H, Takaya K, Iwakura H, Hosoda H, Akamizu T, Arai $\mathrm{Y}$, et al. Transgenic mice overexpressing des-acyl ghrelin show small phenotype. Endocrinology 2005;146:355-64.

[3] Asakawa A, Inui A, Fujimiya M, Sakamaki R, Shinfuku N, Ueta $\mathrm{Y}$, et al. Stomach regulates energy balance via acylated ghrelin and desacyl ghrelin. Gut 2005;54:18-24.

[4] Baldanzi G, Filigheddu N, Cutrupi S, Catapano F, Bonissoni S, Fubini A, et al. Ghrelin and des-acyl ghrelin inhibit cell death in cardiomyocytes and endothelial cells through ERK1/2 and PI 3-kinase/AKT. J Cell Biol 2002;159:1029-37.

[5] Bang AS, Soule SG, Yandle TG, Richards AM, Pemberton CJ. Characterisation of proghrelin peptides in mammalian tissue and plasma. J Endocrinol 2007;192:313-23.

[6] Barazzoni R, Bosutti A, Stebel M, Cattin MR, Roder E, Visintin L, et al. Ghrelin regulates mitochondrial-lipid metabolism gene expression and tissue fat distribution favoring triglyceride deposition in liver but not skeletal muscle. Am J Physiol Endocrinol Metab 2004;288:E228-35.

[7] Barreiro ML, Gaytan F, Castellano JM, Suominen JS, Roa J, Gaytan M, et al. Ghrelin inhibits the proliferative activity of immature Leydig cells in vivo and regulates stem cell factor messenger RNA expression in rat testis. Endocrinology 2004;145:4825-34.

[8] Bassil AK, Häglund Y, Brown J, Rudholm T, Hellström PM, Näslund E, et al. Little or no ability of obestatin to interact with ghrelin or modify motility in the rat gastrointestinal tract. Br J Pharmacol 2007;150:58-64.

[9] Beaumont NJ, Skinner VO, Tan TM, Ramesh BS, Byrne DJ, MacColl GS, et al. Ghrelin can bind to a species of high density lipoprotein associated with paraoxonase. J Biol Chem 2003;278:8877-80.

[10] Bedendi I, Alloatti G, Marcantoni A, Malan D, Catapano F, Ghé C, et al. Cardiac effects of ghrelin and its endogenous derivatives des-octanoyl ghrelin and des-Gln14-ghrelin. Eur J Pharmacol 2003;476:87-95.

[11] Bednarek MA, Feighner SD, Pong SS, McKee KK, Hreniuk DL, Silva MV, et al. Structure-function studies on the new growth hormone-releasing peptide, ghrelin: minimal sequence of ghrelin necessary for activation of growth hormone secretagogue receptor 1a. J Med Chem 2000;43:4370-6.

[12] Bodart V, Febbraio M, Demers A, McNicoll N, Pohankova P, Perreault A, et al. CD36 mediates the cardiovascular action of growth hormone- releasing peptides in the heart. Circ Res 2002;90:844-9.

[13] Bresciani E, Rapetti D, Dona F, Bulgarelli I, Tamiazzo L, Locatelli V, et al. Obestatin inhibits feeding but does not modulate GH and corticosterone secretion in the rat. J Endocrinol Invest 2006;29:RC16-8.
[14] Broglio F, Gottero C, Benso A, Prodam F, Destefanis S, Gauna C, et al. Effects of ghrelin on the insulin and glycemic responses to glucose, arginine, or free fatty acids load in humans. J Clin Endocrinol Metab 2003;88: 4268-72.

[15] Brzozowski T, Konturek PC, Konturek SJ, Kwiecień S, Drozdowicz D, Bielanski W, et al. Exogenous and endogenous ghrelin in gastroprotection against stressinduced gastric damage. Regul Pept 2004;120:39-51.

[16] Brzozowski T, Konturek PC, Drozdowicz D, Konturek SJ, Pawlik M, Sliwowski Z, et al. Role of central and peripheral ghrelin in the mechanism of gastric mucosal defence. Inflammopharmacology 2005;13:45-62.

[17] Burdyga G, Varro A, Dimaline R, Thompson DG, Dockray GJ. Ghrelin receptors in rat and human nodose ganglia: putative role in regulating $\mathrm{CB}-1$ and $\mathrm{MCH}$ receptor abundance. Am J Physiol Gastrointest Liver Physiol 2006;290:G1289-97.

[18] Camina JP. Cell biology of the ghrelin receptor. J Neuroendocrinol 2006;18:65-76.

[19] Camina JP, Campos JF, Caminos JE, Dieguez C, Casanueva FF. Obestatin-mediated proliferation of human retinal pigment epithelial cells: regulatory mechanisms. J Cell Physiol 2007;211:1-9.

[20] Caminos JE, Tena-Sempere M, Gaytán F, Sanchez-Criado JE, Barreiro ML, Nogueiras R, et al. Expression of ghrelin in the cyclic and pregnant rat ovary. Endocrinology 2003;144:1594-602.

[21] Carlini VP, Monzón ME, Varas MM, Cragnolini AB, Schiöth HB, Scimonelli TN, et al. Ghrelin increases anxiety-like behavior and memory retention in rats. Biochem Biophys Res Commun 2002;299:739-43.

[22] Carlini VP, Schiöth HB, Debarioglio SR. Obestatin improves memory performance and causes anxiolytic effects in rats. Biochem Biophys Res Commun 2007;352:907-12.

[23] Cassoni P, Papotti M, Ghè C, Catapano F, Sapino A, Graziani A, et al. Identification, characterization, and biological activity of specific receptors for natural (ghrelin) and synthetic growth hormone secretagogues and analogs in human breast carcinomas and cell lines. J Clin Endocrinol Metab 2001;86:1738-45.

[24] Cassoni P, Ghe C, Marrocco T, Tarabra E, Allia E, Catapano F, et al. Expression of ghrelin and biological activity of specific receptors for ghrelin and des-acyl ghrelin in human prostate neoplasms and related cell lines. Eur J Endocrinol 2004;150:173-84.

[25] Cassoni P, Allia E, Marrocco T, Ghe C, Ghigo E, Muccioli G, et al. Ghrelin and cortistatin in lung cancer: expression of peptides and related receptors in human primary tumors and in vitro effect on the $\mathrm{H} 345$ small cell carcinoma cell line. J Endocrinol Invest 2006;29:781-90.

[26] Chang L, Zhao J, Yang J, Zhang Z, Du J, Tang C. Therapeutic effects of ghrelin on endotoxic shock in rats. Eur J Pharmacol 2003;473:171-6.

[27] Chang L, Ren Y, Liu X, Li WG, Yang J, Geng B, et al. Protective effects of ghrelin on ischemia/reperfusion injury in the isolated rat heart. J Cardiovasc Pharmacol 2004;43:165-70.

[28] Chanoine JP, Wong AC. Ghrelin gene expression is markedly higher in fetal pancreas compared with fetal stomach: effect of maternal fasting. Endocrinology 2004;145:3813-20.

[29] Chanoine JP, Wong AC, Barrios V. Obestatin, acylated and total ghrelin concentrations in the perinatal rat pancreas. Horm Res 2006;66:81-8.

[30] Chartrel N, Alvear-Perez R, Leprince J, Iturrioz X, Reaux-Le Goazigo A, Audinot V, et al. Comment on "obestatin, a peptide encoded by the ghrelin gene, opposes ghrelin's effects on food intake". Science 2005;310:996-9. 
[31] Chen HY, Trumbauer ME, Chen AS, Weingarth DT, Adams JR, Frazier EG, et al. Orexigenic action of peripheral ghrelin is mediated by neuropeptide $\mathrm{Y}$ and agouti-related protein. Endocrinology 2004;145:2607-12.

[32] Chen CY, Chao Y, Chang FY, Chien EJ, Lee SD, Doong ML. Intracisternal des-acyl ghrelin inhibits food intake and non-nutrient gastric emptying in conscious rats. Int J Mol Med 2005;16:695-9.

[33] Conconi MT, Nico B, Guidolin D, Baiguera S, Spinazzi R, Rebuffat P, et al. Ghrelin inhibits FGF-2-mediated angiogenesis in vitro and in vivo. Peptides 2004;25: 2179-85.

[34] Couce ME, Cottam D, Esplen J, Teijeiro R, Schauer P, Burguera B. Potential role of hypothalamic ghrelin in the pathogenesis of human obesity. J Endocrinol Invest 2006;29:599-605.

[35] Cummings DE, Frayo RS, Marmonier C, Aubert R, Chapelot D. Plasma ghrelin levels and hunger scores in humans initiating meals voluntarily without time- and foodrelated cues. Am J Physiol Endocrinol Metab 2004;287:E297-304.

[36] Date Y, Kojima M, Hosoda H, Sawaguchi A, Mondal MS, Suganuma T, et al. Ghrelin, a novel growth hormonereleasing acylated peptide, is synthesized in a distinct endocrine cell type in the gastrointestinal tracts of rats and humans. Endocrinology 2000;141:4255-61.

[37] Delhanty PJ, van der Eerden BC, van der Velde M, Gauna C, Pols HA, Jahr H, et al. Ghrelin and unacylated ghrelin stimulate human osteoblast growth via mitogen-activated protein kinase (MAPK)/phosphoinositide 3-kinase (PI3K) pathways in the absence of GHS-R1a. J Endocrinol 2006;188:37-47.

[38] Depoortere I, De Winter B, Thijs T, De Man J, Pelckmans P, Peeters T. Comparison of the gastroprokinetic effects of ghrelin, GHRP- 6 and motilin in rats in vivo and in vitro. Eur J Pharmacol 2005;515:160-8.

[39] de Smet B, Thijs T, Peeters TL, Depoortere I. Effect of peripheral obestatin on gastric emptying and intestinal contractility in rodents. Neurogastroenterol Motil 2007;19:211-7.

[40] De Vriese C, Hacquebard M, Gregoire F, Carpentier Y, Delporte C. Ghrelin interacts with human plasma lipoproteins. Endocrinology 2007;148:2355-62.

[41] Dixit VD, Schaffer EM, Pyle RS, Collins GD, Sakthivel SK, Palaniappan R, et al. Ghrelin inhibits leptin- and activation-induced proinflammatory cytokine expression by human monocytes and $\mathrm{T}$ cells. J Clin Invest 2004;114:57-66.

[42] Dixit VD, Yang H, Sun Y, Weeraratna AT, Youm YH, Smith RG, et al. Ghrelin promotes thymopoiesis during aging. J Clin Invest 2007;117:2778-90.

[43] Dornonville de la Cour C, Lindström E, Norlén P, Håkanson R. Ghrelin stimulates gastric emptying but is without effect on acid secretion and gastric endocrine cells. Regul Pept 2004;120:23-32.

[44] Dun SL, Brailoiu GC, Brailoiu E, Yang J, Chang JK, Dun NJ. Distribution and biological activity of obestatin in the rat. J Endocrinol 2006;191:481-9.

[45] Duxbury MS, Waseem T, Ito H, Robinson MK, Zinner MJ, Ashley SW, et al. Ghrelin promotes pancreatic adenocarcinoma cellular proliferation and invasiveness. Biochem Biophys Res Commun 2003;309:464-8.

[46] El Eter E, Al Tuwaijiri A, Hagar H, Arafa M. In vivo and in vitro antioxidant activity of ghrelin: Attenuation of gastric ischemic injury in the rat. J Gastroenterol Hepatol 2007;22:1791-9.

[47] Fernandez-Fernandez R, Tena-Sempere M, Navarro VM, Barreiro ML, Castellano JM, Aguilar E, et al. Effects of ghrelin upon gonadotropin-releasing hormone and gonadotropin secretion in adult female rats: In vivo and in vitro studies. Neuroendocrinology 2005;82:245-55.

[48] Filigheddu N, Gnocchi VF, Coscia M, Cappelli M, Porporato $\mathrm{PE}$, Taulli R, et al. Ghrelin and des-acyl ghrelin promote differentiation and fusion of $\mathrm{C} 2 \mathrm{C} 12$ skeletal muscle cells. Mol Biol Cell 2007;18:986-94.

[49] Frascarelli S, Ghelardoni S, Ronca-Testoni S, Zucchi R. Effect of ghrelin and synthetic growth hormone secretagogues in normal and ischemic rat heart. Basic Res Cardiol 2003;98:401-5.

[50] Fujino K, Inui A, Asakawa A, Kihara N, Fujimura M, Fujimiya M. Ghrelin induces fasted motor activity of the gastrointestinal tract in conscious fed rats. J Physiol 2003;550:227-40.

[51] Fukushima N, Hanada R, Teranishi H, Fukue Y, Tachibana $\mathrm{T}$, Ishikawa $\mathrm{H}$, et al. Ghrelin directly regulates bone formation. J Bone Miner Res 2005;20:790-8.

[52] Gauna C, Delhanty PJ, Hofland LJ, Janssen JA, Broglio F, Ross RJ, et al. Ghrelin stimulates, whereas des-octanoyl ghrelin inhibits, glucose output by primary hepatocytes. J Clin Endocrinol Metab 2005;90:1055-60.

[53] Gaytan F, Barreiro ML, Chopin LK, Herington AC, Morales C, Pinilla L, et al. Immunolocalization of ghrelin and its functional receptor, the type 1a growth hormone secretagogue receptor, in the cyclic human ovary. J Clin Endocrinol Metab 2003;88:879-87.

[54] Gaytan F, Barreiro ML, Caminos JE, Chopin LK, Herington AC, Morales C, et al. Expression of ghrelin and its functional receptor, the type 1 a growth hormone secretagogue receptor, in normal human testis and testicular tumors. J Clin Endocrinol Metab 2004;89:400-9.

[55] Ghelardoni S, Carnicelli V, Frascarelli S, Ronca-Testoni S, Zucchi R. Ghrelin tissue distribution: comparison between gene and protein expression. J Endocrinol Invest 2006;29:115-21.

[56] Gnanapavan S, Kola B, Bustin SA, Morris DG, McGee P, Fairclough $P$, et al. The tissue distribution of the mRNA of ghrelin and subtypes of its receptor, GHS-R, in humans. J Clin Endocrinol Metab 2002;87:2988-91.

[57] Gonzalez-Rey E, Chorny A, Delgado M. Therapeutic action of ghrelin in a mouse model of colitis. Gastroenterology 2006;130:1707-20.

[58] Gourcerol G, St-Pierre DH, Tache Y. Lack of obestatin effects on food intake: should obestatin be renamed ghrelin-associated peptide (GAP)? Regul Pept 2007;141:1-7.

[59] Granata R, Settanni F, Trovato L, Destefanis S, Gallo D, Martinetti M, et al. Unacylated as well as acylated ghrelin promotes cell survival and inhibit apoptosis in HIT-T15 pancreatic beta-cells. J Endocrinol Invest 2006;29:RC19-22.

[60] Granata R, Settanni F, Gallo D, Trovato L, Biancone L, Cantaluppi V, et al. Obestatin promotes survival of pancreatic-cells and human islets and induces expression of genes involved in the regulation of cell mass and function. Diabetes 2007 [Epub ahead of print].

[61] Green BD, Irwin N, Flatt PR. Direct and indirect effects of obestatin peptides on food intake and the regulation of glucose homeostasis and insulin secretion in mice. Peptides 2007;28:981-7.

[62] Guan XM, Yu H, Palyha OC, McKee KK, Feighner SD, Sirinathsinghji DJ, et al. Distribution of mRNA encoding the growth hormone secretagogue receptor in brain and peripheral tissues. Brain Res Mol Brain Res 1997;48:23-9.

[63] Guo ZF, Zheng X, Qin YW, Hu JQ Chen SP, Zhang Z. Circulating Preprandial Ghrelin to Obestatin Ratio Is Increased in Human Obesity. J Clin Endocrinol Metab 2007;92:1875-80.

[64] Harada T, Nakahara T, Yasuhara D, Kojima S, Sagiyama K, Amitani H, et al. Obestatin, acyl ghrelin, and des-acyl ghrelin responses to an oral glucose tolerance test in the 
restricting type of anorexia nervosa. Biol Psychiatry 2008;63:245-7.

[65] Hehir MP, Glavey SV, Morrison JJ. Uterorelaxant effect of ghrelin on human myometrial contractility. Am J Obstet Gynecol 2008;198:323.e1-5.

[66] Heijboer AC, van den Hoek AM, Parlevliet ET, Havekes LM, Romijn JA, Pijl H, et al. Ghrelin differentially affects hepatic and peripheral insulin sensitivity in mice. Diabetologia 2006;49:732-8.

[67] Hewson AK, Dickson SL. Systemic administration of ghrelin induces Fos and Egr-1 proteins in the hypothalamic arcuate nucleus of fasted and fed rats. J Neuroendocrinol 2000;12:1047-9.

[68] Holst B, Egerod KL, Schild E, Vickers SP, Cheetham S, Gerlach LO, et al. GPR39 signaling is stimulated by zinc ions but not by obestatin. Endocrinology 2007;148: 13-20.

[69] Hosoda H, Kojima M, Matsuo H, Kangawa K. Purification and characterization of rat des-Gln14-ghrelin, a second endogenous ligand for the growth hormone secretagogue receptor. J Biol Chem 2000;275:21995-2000.

[70] Hosoda H, Kojima M, Mizushima T, Shimizu S, Kangawa K. Structural divergence of human ghrelin. Identification of multiple ghrelin-derived molecules produced by posttranslational processing. J Biol Chem 2003;278:64-70.

[71] Hosoda H, Doi K, Nagaya N, Okumura H, Nakagawa E, Enomoto $\mathrm{M}$, et al. Optimum collection and storage conditions for ghrelin measurements: octanoyl modification of ghrelin is rapidly hydrolyzed to desacyl ghrelin in blood samples. Clin Chem 2004;50:1077-80.

[72] Howard AD, Feighner SD, Cully DF, Arena JP, Liberator PA, Rosenblum CI, et al. A receptor in pituitary and hypothalamus that functions in growth hormone release. Science 1996;273:974-7.

[73] Iglesias MJ, Salgado A, Piñeiro R, Rodiño BK, Otero MF, Grigorian L, et al. Lack of effect of the ghrelin gene-derived peptide obestatin on cardiomyocyte viability and metabolism. J Endocrinol Invest 2007;30:470-6.

[74] Jeffery PL, Herington AC, Chopin LK. Expression and action of the growth hormone releasing peptide ghrelin and its receptor in prostate cancer cell lines. J Endocrinol 2002;172:R7-11.

[75] Jeffery PL, Duncan RP, Yeh AH, Jaskolski RA, Hammond DS, Herington AC, et al. Expression of the ghrelin axis in the mouse: an exon 4-deleted mouse proghrelin variant encodes a novel C terminal peptide. Endocrinology 2005;146:432-40.

[76] Kim MS, Yoon CY, Jang PG, Park YJ, Shin CS, Park HS, et al. The mitogenic and antiapoptotic actions of ghrelin in 3T3L1 adipocytes. Mol Endocrinol 2004;18:2291-301.

[77] Kanamoto N, Akamizu T, Tagami T, Hataya Y, Moriyama $\mathrm{K}$, Takaya $\mathrm{K}$, et al. Genomic structure and characterization of the $5^{\prime}$-flanking region of the human ghrelin gene. Endocrinology 2004;145:4144-53.

[78] Kapica M, Zabielska M, Puzio I, Jankowska A, Kato I, Kuwahara A, et al. Obestatin stimulates the secretion of pancreatic juice enzymes through a vagal pathway in anaesthetized rats-preliminary results. J Physiol Pharmacol 2007;58:123-30.

[79] Kasımay O, Işeri SO, Barlas A, Bangir D, Yeğen C, Arbak S, et al. Ghrelin ameliorates pancreaticobiliary inflammation and associated remote organ injury in rats. Hepatol Res 2006;36:11-9.

[80] Kawamura K, Sato N, Fukuda J, Kodama H, Kumagai J, Tanikawa $\mathrm{H}$, et al. Ghrelin inhibits the development of mouse preimplantation embryos in vitro. Endocrinology 2003;144:2623-33.

[81] Kishimoto M, Okimura $Y$, Nakata $H$, Kudo T, Iguchi G, Takahashi $Y$, et al. Cloning and characterization of the $5^{\prime}-$ flanking region of the human ghrelin gene. Biochem Biophys Res Commun 2003;305:186-92.

[82] Kleinz MJ, Maguire JJ, Skepper JN, Davenport AP. Functional and immunocytochemical evidence for a role of ghrelin and des-octanoyl ghrelin in the regulation of vascular tone in man. Cardiovasc Res 2006;69: 227-35.

[83] Kojima M, Hosoda H, Date Y. Ghrelin is a growthhormone-releasing acylated peptide from stomach. Nature 1999;402:656-60.

[84] Kojima M, Kangawa K. Ghrelin: structure and function. Physiol Rev 2005;85:495-522.

[85] Koo GC, Huang C, Camacho R, Trainor C, Blake JT, Sirotina-Meisher A, et al. Immune enhancing effect of a growth hormone secretagogue. J Immunol 2001;166:4195201.

[86] Lagaud GJ, Young A, Acena A, Morton MF, Barrett TD, Shankley NP. Obestatin reduces food intake and suppresses body weight gain in rodents. Biochem Biophys Res Commun 2007;357:264-9.

[87] Lago R, Gomez R, Dieguez C, Gomez-Reino JJ, Lago F, Gualillo O. Unlike ghrelin, obestatin does not exert any relevant activity in chondrocytes. Ann Rheum Dis 2007;66:1399-400.

[88] Lanfranco F, Bonelli L, Broglio F, Me E, Baldi M, di Bisceglie C, et al. Ghrelin inhibits LH pulsatility in humans. In: Proceedings of the 88th Endocrine Society Meeting (ENDO2006); 2006. p. P3-807.

[89] Lauwers E, Landuyt B, Arckens L, Schoofs L, Luyten W. Obestatin does not activate orphan $\mathrm{G}$ protein-coupled receptor GPR39. Biochem Biophys Res Commun 2006;351:21-5.

[90] Lawrence CB, Snape AC, Baudoin FM, Luckman SM. Acute central ghrelin and GH secretagogues induce feeding and activate brain appetite centers. Endocrinology 2002;143:155-62.

[91] Leite-Moreira AF, Soares JB. Physiological, pathological and potential therapheutic roles of ghrelin. Drug Discov Today 2007;12:276-88.

[92] Li L, Zhang LK, Pang YZ, Pan CS, Qi YF, Chen L, et al. Cardioprotective effects of ghrelin and des-octanoyl ghrelin on myocardial injury induced by isoproterenol in rats. Acta Pharmacol Sin 2006;27:527-35.

[93] Li WG, Gavrila D, Liu X, Wang L, Gunnlaugsson S, Stoll LL, et al. Ghrelin inhibits proinflammatory responses and nuclear factor-kappa B activation in human endothelial cells. Circulation 2004;109:2221-6.

[94] Li Y, Wu X, Zhao Y, Chen S, Owyang C. Ghrelin acts on the dorsal vagal complex to stimulate pancreatic protein secretion. Am J Physiol Gastrointest Liver Physiol 2006;290:G1350-8.

[95] Lin Y, Matsumura K, Fukuhara M, Kagiyama S, Fujii K, Iida M. Ghrelin acts at the nucleus of the solitary tract to decrease arterial pressure in rats. Hypertension 2004;43:977-82.

[96] Maccarinelli G, Sibilia V, Torsello A, Raimondo F, Pitto M, Giustina A, et al. Ghrelin regulates proliferation and differentiation of osteoblastic cells. J Endocrinol 2005;184:249-56.

[97] Malagón MM, Luque RM, Ruiz-Guerrero E, RodríguezPacheco F, García-Navarro S, Casanueva FF, et al. Intracellular signalling mechanisms mediating ghrelinstimulated growth hormone release in somatotropes. Endocrinology 2003;144:5372-80.

[98] Martini AC, Fernandez-Fernandez R, Tovar S, Navarro VM, Vigo E, Vazquez MJ, et al. Comparative analysis of the effects of ghrelin and un-acylated ghrelin upon luteinizing hormone secretion in male rats. Endocrinology 2006;147:2374-82. 
[99] Matsuda K, Miura T, Kaiya H, Maruyama K, Shimakura S, Uchiyama M, et al. Regulation of food intake by acyl and des-acyl ghrelins in the goldfish. Peptides 2006;27: 2321-5.

[100] Matsumoto M, Hosoda H, Kitajima Y, Morozumi N, Minamitake Y, Tanaka S, et al. Structure-activity relationship of ghrelin: pharmacological study of ghrelin peptides. Biochem Biophys Res Commun 2001;287:42-6.

[101] Mazzocchi G, Neri G, Rucinski M, Rebuffat P, Spinazzi R, Malendowicz LK, et al. Ghrelin enhances the growth of cultured human adrenal zona glomerulosa cells by exerting MAPK-mediated proliferogenic and antiapoptotic effects. Peptides 2004;25:1269-77.

[102] Mészárosová M, Sirotkin AV, Grossmann R, Darlak K, Valenzuela $F$. The effect of obestatin on porcine ovarian granulosa cells. Anim Reprod Sci 2007 [Epub ahead of print].

[103] Mozid AM, Tringali G, Forsling ML, Hendricks MS, Ajodha $\mathrm{S}$, Edwards R, et al. Ghrelin is released from rat hypothalamic explants and stimulates corticotrophinreleasing hormone and arginine-vasopressin. Horm Metab Res 2003;35:455-9.

[104] Muccioli G, Pons N, Ghè C, Catapano F, Granata R, Ghigo E. Ghrelin and des-acyl ghrelin both inhibit isoproterenolinduced lipolysis in rat adipocytes via a non-type $1 \mathrm{a}$ growth hormone secretagogue receptor. Eur J Pharmacol 2004;498:27-35.

[105] Murata M, Okimura Y, Iida K, Matsumoto M, Sowa H, Kaji $\mathrm{H}$, et al. Ghrelin modulates the downstream molecules of insulin signaling in hepatoma cells. J Biol Chem 2002;277:5667-74.

[106] Nagaya N, Kojima M, Uematsu M, Yamagishi M, Hosoda H, Oya $\mathrm{H}$, et al. Hemodynamic and hormonal effects of human ghrelin in healthy volunteers. Am J Physiol Regul Integr Comp Physiol 2001;280:R1483-7.

[107] Nagaya N, Miyatake K, Uematsu M, Oya H, Shimizu W, Hosoda $\mathrm{H}$, et al. Hemodynamic, renal, and hormonal effects of ghrelin infusion in patients with chronic heart failure. J Clin Endocrinol Metab 2001;86:5854-9.

[108] Nakahara K, Nakagawa M, Baba Y, Sato M, Toshinai K, Date $Y$, et al. Maternal ghrelin plays an important role in rat fetal development during pregnancy. Endocrinology 2006;147:1333-42.

[109] Nishi Y, Hiejima H, Hosoda H, Kaiya H, Mori K, Fukue Y, et al. Ingested medium-chain fatty acids are directly utilized for the acyl modification of ghrelin. Endocrinology 2005;146:2255-64.

[110] Nishi Y, Hiejima H, Mifune H, Sato T, Kangawa K, Kojima M. Developmental changes in the pattern of ghrelin's acyl modification and the levels of acyl-modified ghrelins in murine stomach. Endocrinology 2005;146:2709-15.

[111] Nogueiras R, Pfluger P, Tovar S, Arnold M, Mitchell S, Morris A, et al. Effects of obestatin on energy balance and growth hormone secretion in rodents. Endocrinology 2007;148:21-6.

[112] Ott V, Fasshauer M, Dalski A, Meier B, Perwitz N, Klein HH, et al. Direct peripheral effects of ghrelin include suppression of adiponectin expression. Horm Metab Res 2002;34:640-5.

[113] Park JM, Kakimoto T, Kuroki T, Shiraishi R, Fujise T, Iwakiri R, et al. Suppression of intestinal mucosal apoptosis by ghrelin in fasting rats. Exp Biol Med (Maywood) 2008;233:148-56.

[114] Patel AD, Stanley SA, Murphy KG, Frost GS, Gardiner JV, Kent AS, et al. Ghrelin stimulates insulin-induced glucose uptake in adipocytes. Regul Pept 2006;134:17-22.

[115] Patterson M, Murphy KG, le Roux CW, Ghatei MA, Bloom SR. Characterization of ghrelin-like immunoreactivity in human plasma. J Clin Endocrinol Metab 2005;90:2205-11.
[116] Pemberton C, Wimalasena P, Yandle T, Soule S, Richards M. C-terminal pro-ghrelin peptides are present in the human circulation. Biochem Biophys Res Commun 2003;310:567-73.

[117] Pemberton CJ, Tokola H, Bagi Z, Koller A, Pöntinen J, Ola A, et al. Ghrelin induces vasoconstriction in the rat coronary vasculature without altering cardiac peptide secretion. Am J Physiol Heart Circ Physiol 2004;287:H1522-9.

[118] Pénicaud L, Leloup C, Fioramonti X, Lorsignol A, Benani A. Brain glucose sensing: a subtle mechanism. Curr Opin Clin Nutr Metab Care 2006;9:458-62.

[119] Popovic V, Miljic D, Micic D, Damjanovic S, Arvat E, Ghigo $E$, et al. Ghrelin main action on the regulation of growth hormone release is exerted at hypothalamic level. J Clin Endocrinol Metab 2003;88:3450-3.

[120] Qader SS, Håkanson R, Rehfeld JF, Lundquist I, Salehi A. Proghrelin-derived peptides influence the secretion of insulin, glucagon, pancreatic polypeptide and somatostatin: a study on isolated islets from mouse and rat pancreas. Regul Pept 2007;146:230-7.

[121] Rak A, Gregoraszczuk EL. Local feedback loop of ghrelinGH in the pig ovary: action on estradiol secretion, aromatase activity and cell apoptosis. Growth Horm IGF Res 2007;18:221-7.

[122] Rocha-Sousa A, Saraiva J, Henriques-Coelho T, Falcão-Reis F, Correia-Pinto J, Leite-Moreira AF. Ghrelin as a novel locally produced relaxing peptide of the iris sphincter and dilator muscles. Exp Eye Res 2006;83:1179-87.

[123] Rossi F, Bertone C, Petricca S, Santiemma V. Ghrelin inhibits angiotensin II-induced migration of human aortic endothelial cells. Atherosclerosis 2006;192:291-7.

[124] Salehi A, Dornonville de la Cour C, Håkanson R, Lundquist I. Effects of ghrelin on insulin and glucagon secretion: a study of isolated pancreatic islets and intact mice. Regul Pept 2004;118:143-50.

[125] Samson WK, White MM, Price C, Ferguson AV. Obestatin acts in brain to inhibit thirst. Am J Physiol Regul Integr Comp Physiol 2007;292:R637-43.

[126] Sato M, Nakahara K, Goto S, Kaiya H, Miyazato M, Date Y, et al. Effects of ghrelin and des-acyl ghrelin on neurogenesis of the rat fetal spinal cord. Biochem Biophys Res Commun 2006;350:598-603.

[127] Seoane LM, Al-Massadi O, Pazos Y, Pagotto U, Casanueva FF. Central obestatin administration does not modify either spontaneous or ghrelin-induced food intake in rats. J Endocrinol Invest 2006;29:RC13-5.

[128] Shanado Y, Kometani M, Uchiyama H, Koizumi S, Teno N. Lysophospholipase I identified as a ghrelin deacylation enzyme in rat stomach. Biochem Biophys Res Commun 2004;325:1487-94

[129] Shimbara T, Mondal MS, Kawagoe T, Toshinai K, Koda S, Yamaguchi $\mathrm{H}$, et al. Central administration of ghrelin preferentially enhances fat ingestion. Neurosci Lett 2004;369:75-9.

[130] Shimizu Y, Chang EC, Shafton AD, Ferens DM, Sanger GJ, Witherington J, et al. Evidence that stimulation of ghrelin receptors in the spinal cord initiates propulsive activity in the colon of the rat. J Physiol 2006;576:329-38.

[131] Sibilia V, Bresciani E, Lattuada N, Rapetti D, Locatelli V, De Luca V, et al. Intracerebroventricular acute and chronic administration of obestatin minimally affect food intake but not weight gain in the rat. J Endocrinol Invest 2006;29:RC31-4.

[132] Sibilia V, Muccioli G, Deghenghi R, Pagani F, De Luca V, Rapetti D, et al. Evidence for a role of the GHS-R1a in ghrelin inhibition of gastric acid secretion in the rat. J Neuroendocrinol 2006;18:122-8.

[133] Soares JB, Rocha-Sousa A, Castro-Chaves P, HenriquesCoelho T, Leite-Moreira AF. Inotropic and lusitropic effects 
of ghrelin and their modulation by the endocardial endothelium, NO, prostaglandins, GHS-R1a and $\mathrm{KCa}$ channels. Peptides 2006;27:1616-23.

[134] Sun Y, Ahmed S, Smith RG. Deletion of ghrelin impairs neither growth nor appetite. Mol Cell Biol 2003;23:7973-81.

[135] Sun Y, Wang P, Zheng H, Smith RG. Ghrelin stimulation of growth hormone release and appetite is mediated through the growth hormone secretagogue receptor. Proc Natl Acad Sci USA 2004;101:4679-84.

[136] Sun Y, Butte NF, Garcia JM, Smith RG. Characterization of adult ghrelin and ghrelin receptor knockout mice under positive and negative energy balance. Endocrinology 2008;149:843-50.

[137] Szentirmai E, Krueger JM. Obestatin alters sleep in rats. Neurosci Lett 2006;404:222-6.

[138] Tachibana T, Kaiya H, Denbow DM, Kangawa K, Furuse M. Central ghrelin acts as an anti-dipsogenic peptide in chicks. Neurosci Lett 2006;405:241-5.

[139] Tack J, Depoortere I, Bisschops R, Verbeke K, Janssens J, Peeters $\mathrm{T}$. Influence of ghrelin on gastric emptying and meal-related symptoms in idiopathic gastroparesis. Aliment Pharmacol Ther 2005;22:847-53.

[140] Tack J, Depoortere I, Bisschops R, Delporte C, Coulie B, Meulemans A, et al. Influence of ghrelin on interdigestive gastrointestinal motility in humans. Gut 2006;55:327-33.

[141] Tang-Christensen M, Vrang N, Ortmann S, Bidlingmaier M, Horvath TL, Tschöp M. Central administration of ghrelin and agouti-related protein (83-132) increases food intake and decreases spontaneous locomotor activity in rats. Endocrinology 2004;145:4645-52.

[142] Tena-Sempere M, Barreiro ML, González LC, Gaytán F, Zhang FP, Caminos JE, et al. Novel expression and functional role of ghrelin in rat testis. Endocrinology 2002;143:711-25.

[143] Tesauro M, Schinzari F, Iantorno M, Rizza S, Melina D, Lauro D, et al. Ghrelin improves endothelial function in patients with metabolic syndrome. Circulation 2005;112:2986-92.

[144] Thompson NM, Gill DA, Davies R, Loveridge N, Houston PA, Robinson IC, et al. Ghrelin and des-octanoyl ghrelin promote adipogenesis directly in vivo by a mechanism independent of the type 1a growth hormone secretagogue receptor. Endocrinology 2004;145:234-42.

[145] Tigno XT, Selaru IK, Angeloni SV, Hansen BC. Is microvascular flow rate related to ghrelin, leptin and adiponectin levels? Clin Hemorheol Microcirc 2003;29: 409-16.

[146] Toshinai K, Date Y, Murakami N, Shimada M, Mondal MS, Shimbara T, et al. Ghrelin-induced food intake is mediated via the orexin pathway. Endocrinology 2003;144:1506-12.

[147] Toshinai K, Yamaguchi H, Sun Y, Smith RG, Yamanaka A, Sakurai $\mathrm{T}$, et al. Des-acyl ghrelin induces food intake by a mechanism independent of the growth hormone secretagogue receptor. Endocrinology 2006;147:2306-14.

[148] Tsubone T, Masaki T, Katsuragi I, Tanaka K, Kakuma T, Yoshimatsu $\mathrm{H}$. Ghrelin regulates adiposity in white adipose tissue and UCP1 mRNA expression in brown adipose tissue in mice. Regul Pept 2005;130:97-103.

[149] Tsubota Y, Owada-Makabe K, Yukawa K, Maeda M. Hypotensive effect of des-acyl ghrelin at nucleus tractus solitarii of rat. Neuroreport 2005;16:163-6.
[150] Van der Lely AJ, Tschop M, Heiman ML, Ghigo E. Biological, physiological, pathophysiological, and pharmacological aspects of ghrelin. Endocr Rev 2004;25:426-57.

[151] Volante M, Allìa E, Gugliotta P, Funaro A, Broglio F, Deghenghi R, et al. Expression of ghrelin and of the GH secretagogue receptor by pancreatic islet cells and related endocrine tumors. J Clin Endocrinol Metab 2002;87:1300-8.

[152] Wang WG, Chen X, Jiang H, Jiang ZY. Effects of ghrelin on glucose-sensing and gastric distension sensitive neurons in rat dorsal vagal complex. Regul Pept 2008;146:169-75.

[153] Wei W, Wang G, Qi X, Englander EW, Greeley GH. Characterization and regulation of the rat and human ghrelin promoters. Endocrinology 2005;146:1611-25.

[154] Weikel JC, Wichniak A, Ising M, Brunner H, Friess E, Held $\mathrm{K}$, et al. Ghrelin promotes slow-wave sleep in humans. Am J Physiol Endocrinol Metab 2003;284:E407-15.

[155] Williams DL, Grill HJ, Cummings DE, Kaplan JM. Vagotomy dissociates short- and long-term controls of circulating ghrelin. Endocrinology 2003;144:5184-7.

[156] Wren AM, Seal LJ, Cohen MA, Brynes AE, Frost GS, Murphy $\mathrm{KG}$, et al. Ghrelin enhances appetite and increases food intake in humans. J Clin Endocrinol Metab 2001;86: 5992.

[157] Yakabi K, Ro S, Onouhi T, Tanaka T, Ohno S, Miura S, et al. Histamine mediates the stimulatory action of ghrelin on acid secretion in rat stomach. Dig Dis Sci 2006;51: 1313-21.

[158] Yamamoto D, Ikeshita N, Daito R, Herningtyas EH, Toda K, Takahashi K, et al. Neither intravenous nor intracerebroventricular administration of obestatin affects the secretion of GH, PRL, TSH and ACTH in rats. Regul Pept 2007;138:141-4.

[159] Yasuda T, Masaki T, Kakuma T, Yoshimatsu H. Centrally administered ghrelin suppresses sympathetic nerve activity in brown adipose tissue of rats. Neurosci Lett 2003;349:75-8.

[160] Yeh AH, Jeffery PL, Duncan RP, Herington AC, Chopin LK. Ghrelin and a novel preproghrelin isoform are highly expressed in prostate cancer and ghrelin activatesmitogen-activated proteinkinasein prostate cancer. Clin Cancer Res 2005;11:8295-303.

[161] Yoshimoto A, Mori K, Sugawara A, Mukoyama M, Yahata $\mathrm{K}$, Suganami T, et al. Plasma ghrelin and desacyl ghrelin concentrations in renal failure. J Am Soc Nephrol 2002;13:2748-52.

[162] Zhang JV, Ren P-G, Avsian-Kretchmer O, Luo C-W, Rauch $\mathrm{R}$, Klein C, et al. Obestatin, a peptide encoded by the ghrelin gene, opposes ghrelin's effects on food intake. Science 2005;11:996-9.

[163] Zhu X, Cao Y, Voodg K, Steiner DF. On the processing of proghrelin to ghrelin. J Biol Chem 2006;281:38867-70.

[164] Zizzari P, Longchamps R, Epelbaum J, Bluet-Pajot MT. Obestatin partially affects ghrelin stimulation of food intake and GH secretion in rodents. Endocrinology 2007;148:1648-53.

[165] Zhao CM, Furnes MW, Stenström B, Kulseng B, Chen D. Characterization of obestatin- and ghrelin-producing cells in the gastrointestinal tract and pancreas of rats: an immunohistochemical and electron-microscopic study. Cell Tissue Res 2007;331:575-87. 